AL-AZHAR UNIVERSITY

BULLETIN OF THE FACULTY OF

LANGUAGES \& TRANSLATION

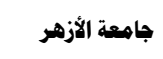

هجلة كية اللغات والترجمة

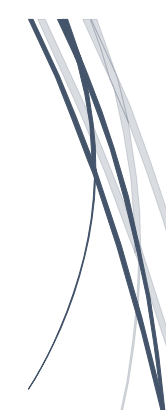

القيم التربوية في مسرح الطفل

مجموعة "تيراور كنر: الماس والحصىى" نموذجاً

دراسة تحليلية

دأسامة محمد شلبي

قسم اللغة الأردية وآدآها

كلية اللغات والترجمة

جامعة الأزهر 


\section{القيم التربوية في مسرح الطفل مجموعة "بيرا اور كنكر: الماس والحصى" نموذجاً \\ دراسة تحليلية}

أسامة محمد شلبى

قسم اللغة الأردية وآدابها، كلية اللغات والترجمة، جامعة الأزهر، القاهرة، مصر البريد الإليكترونى: usamashalaby@azhar.edu.eg

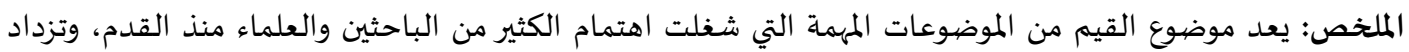

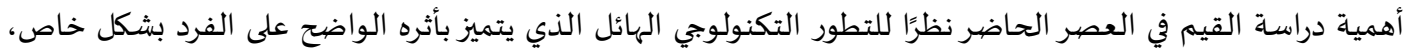

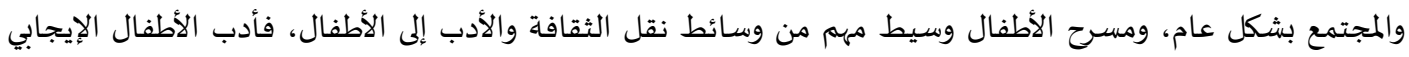

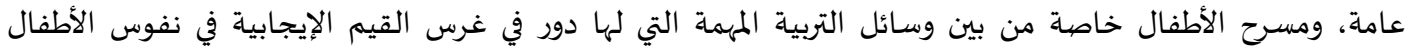

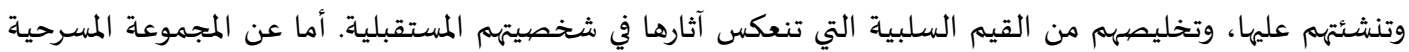

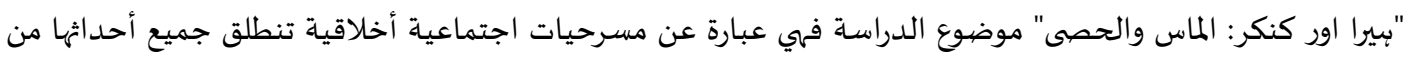

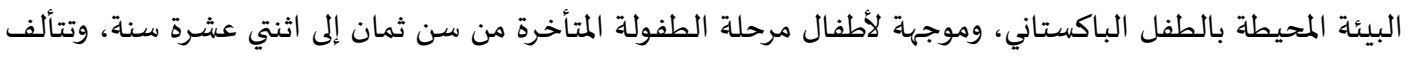

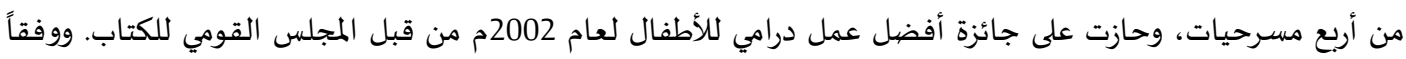

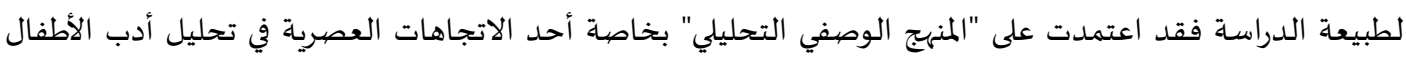
وهو "التحليل التتبعي القيمي". كلمات مفتاحية: القيم التربوية، مسرح الطفل، سيد نظرزيدي، مجموعة "بيرا اور كنكر".

\section{Educational values in children's plays}

\section{Usama Mohammed Shalaby} The "Diamond and Pebbles" ... An analytical study

Department of Urdu, Faculty of Lang. \& Translation.

\section{Al-Azhar University, Cairo, Egypt.}

E-mail: usamashalaby@azhar.edu.eg

Abstract: Values is an important topic that has occupied the interest of many scholars since ancient times. The importance of studying values increases in the present due to the tremendous technological development that is characterized by its clear impact on the individual, and society in general. Children's plays are an important means of transmitting culture and literature to children. Positive children's literature in general, and children's plays are among the important means of education that have a role in instilling positive values in the children and bringing them up and ridding them of negative values that are reflected in their future personality. As for the "Diamonds and Pebbles" plays, they are socio-moral plays that take place from the environment surrounding the Pakistani child and are directed to late childhood from eight to twelve years. They consist of four plays and won the prize of best drama for children for the year 2002 by the National Book Council. The study depended on the (descriptive and analytical) method, especially one of the modern trends in the analysis of children's literature, which is "value tracer analysis".

Keywords: Educational Values, Children's Plays, Syed Nazar Zaidi, "Diamond and Gravel" plays. 


\section{المقدمة}

يعد موضوع القيم من الموضوعات المهمة التي شغلت اهتمام الكثير من الباحثني والعلماء منذ القدم، وتزداد أهمية دراسة القيم في العصر الحاضر نظرًا للتطور التكنولوجي الهائل الذي يتميز بأثره الواضح على الفرد بشكل خاص، والمجتمع بشكل عام، ونشكل القيم

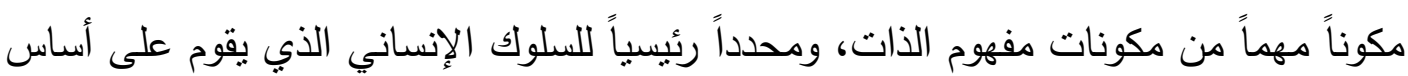
توافر مجموعة من القيم لدى كل فرد في المجتمع، بل وتلعب دوراً هاماً على المستوبين الفردي والمجتمي، حيث يحتاج إليها الفرد في تفاعله مع المجتمع كضابط ومحدد وموجه

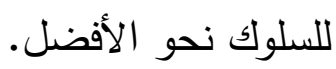

ومسرح الأطفال وسيط مهم من وسائط نقل الثقافة والأدب إلى الأطفال، فأدب التب الأطفال الإيجابي عامة، ومسرح الأطفال خاصة من بين وسائل التربية المهمة التي لها دور في غرس القيم الإيجابية في نفوس الأطفال وتتشئتهم عليها إن دينية أو معرفية أو اجتماعية

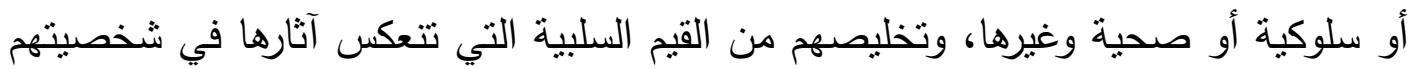
المستقبلية، وهو مثله مثل الوسائط الأخرى لأدب الأطفال يحرك مشاعر الطفل وذهنه وعقله، وهنه فيقوده إلى التفكير، وتتمية السلوك، واحترام القيم النبيلة والتحلي بها، وازدراء المفاهيم البالية

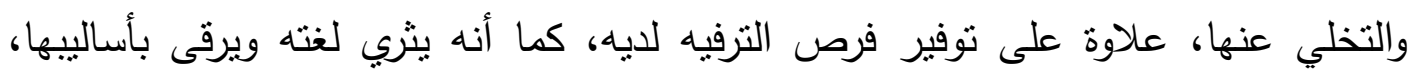
وينمّي قدراته التعبيرية عن الأفكار والمشاعر والاحتياجات. أما عن المجموعة المسرحية "بير|اوركنزر: الماس والحصى" موضوع الدراسة فهي عبارة عن مسرحيات اجتماعية أخلاقية تتطلق جميع أحداثها من البيئة المحيطة بالطفل الباكستاني، وموجهة لأطفال مرحلة الطفولة المتأخرة الممتدة من سن ثمان سنوات إلى اثثتي عثرة سنة، وتقع في ست وثلاثين صفحة، وتتألف من أربع مسرحيات: الأولى بعنوان "ايميراوركنر: الماس

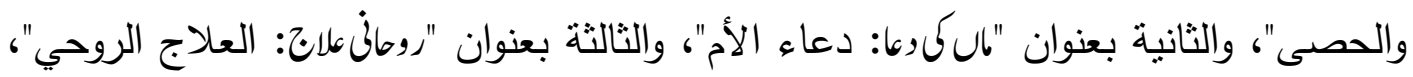

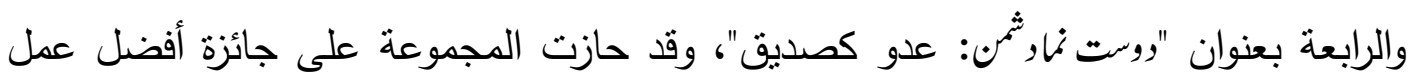
درامي للأطفال لعام 2002م من قبل المجلس القومي للكتاب، ونشرت للمرة الأولى عام 
ووفقاً لطبيعة الدراسة فقد اعتمدت على "المنهج الوصفي التحليلي" بخاصة أحد الاتجاهات العصرية في تحليل أدب الأطفال وهو "التحليل التتبعي القيمي" الذي يرصد نتبع القيم في أعمال الأطفال الموجهة إليهم، وبقصد به معرفة مدي تتابع وتدفق القيم وتكاملها داخل أدب الأطفال الخاضع للتحليل، ومدي نوافق وضوح فكرة الكتاب ومزج الخيال مع الواقع والبناء التسلسلي في الكتاب، ويركز على مضمون القصة، لا عن طريق السرد والتقربر؛ بل عن طريق تضمين القيم وسط الحقائق والمعلومات والمفاهيم والأحداث الدرامية. ورغم توفر بعض الدراسات الجامعية الحديثة التى توجه بها أصحابها إلى دراسة أدب ولى واهب الأطفال الأردي، إلا أنه لم يتتاول أحد منهم البحث في مسرح الطفل عند الأديب الباكستاني "سيد نظر زيدى" وبخاصة مجموعته المسرحية "يميراوركنر : الماس والحصىى" موضوع الدراسة. وقد قمت بتقسيم هذا البحث إلى تمهيد ومبحثين، فبدأت بتمهيد تتاولت فيه لمحة عن فئن تطور مسرح الطفل الأردي وأهم رواده، ثم جاء المبحث الأول بعنوان: "سيد نظر زيدى: حياته وأعماله" واستعرضت فيه نبذة عن الأديب ومؤلفاته في مختلف صنوف الأدب الأردي عامة، وفي أدب الطفل خاصة، وأتمدت ذلك بعرض موضوعي للمجموعة المسرحية موضوع

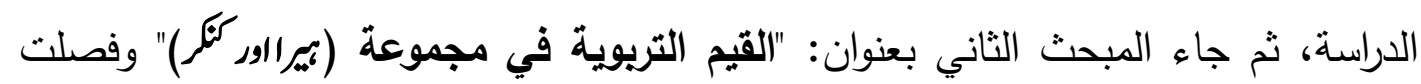
الحديث فيه عن مجموعة القيم التربوية التي تضمنتها المجموعة المسرحية من قيم اجتماعية ودينية وأخلاقية ومعرفية، وذيلت ذلك كله بخاتمة تضم أهم النتائج التي توصل إلبها البحث،

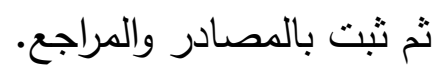
والله أسأل أن أكون قد وفقت في اختيار الموضوع، وقدمته بالدراسة المناسبة له ليكون إضافة جديدة إلى جهود من سبقوني في مجال أدب الطفل الأردي بوجه عام، والذي ما يزال خصباً يحتاج إلى المزيد من الأبحاث والدراسات. 


\section{تمهيخ}

عند الحديث عن مسرح الطفل الأردي نجد أن بداياته في الأردية كانت في أوائل

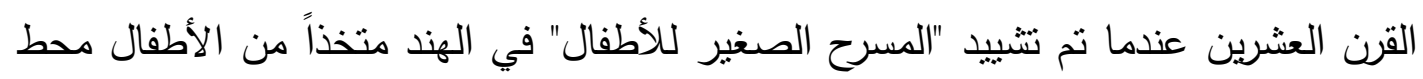

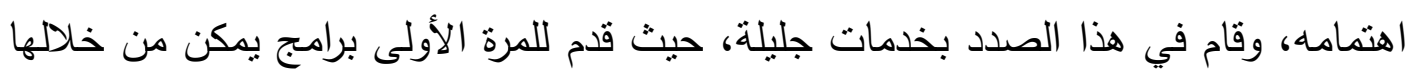

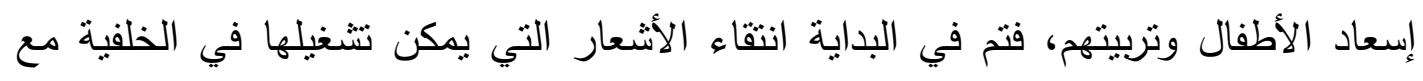

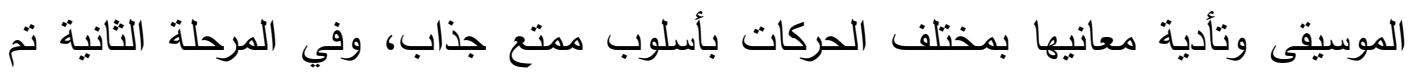

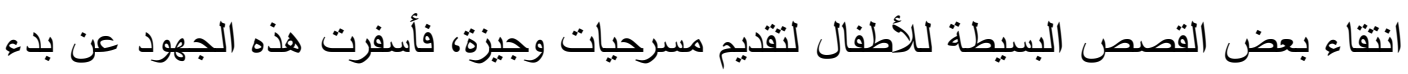

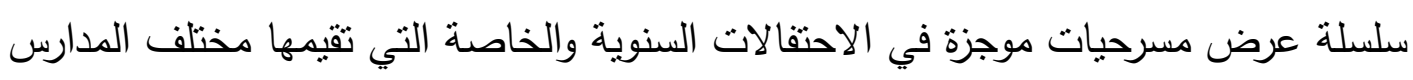

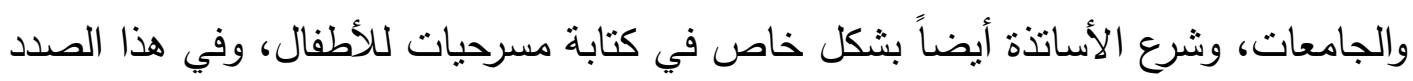

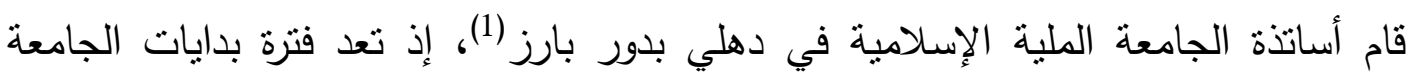

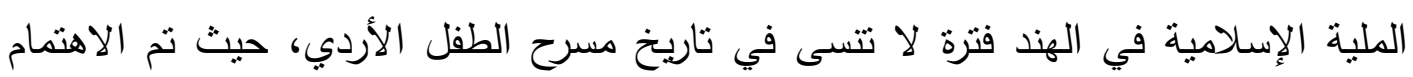

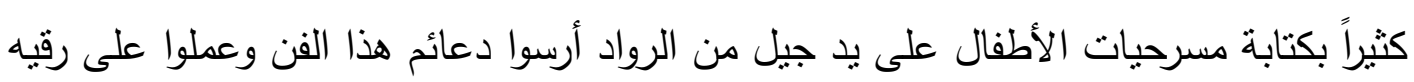

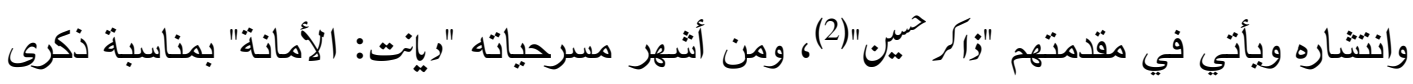

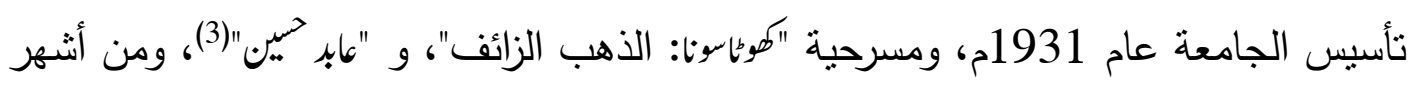

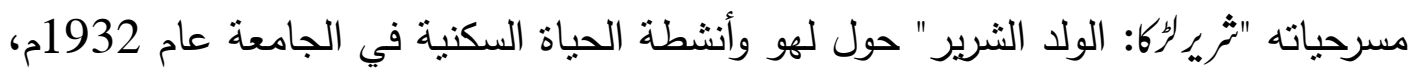

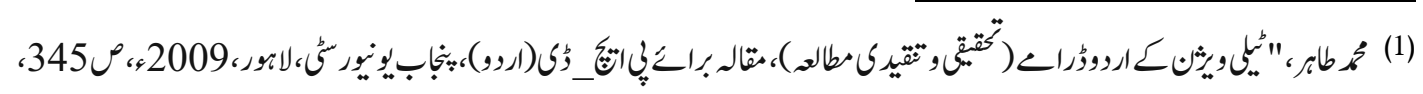
.346

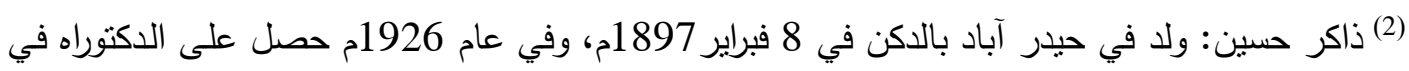

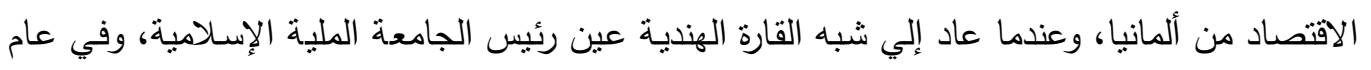

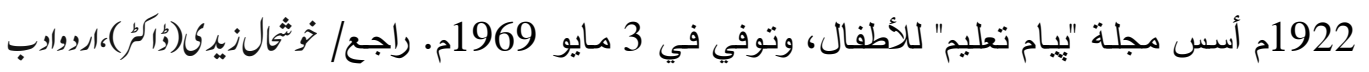

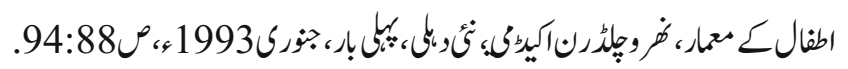

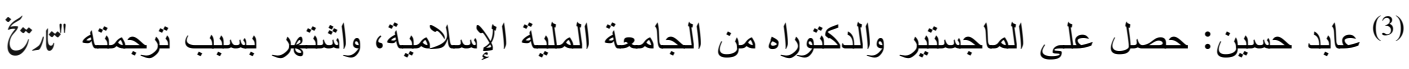

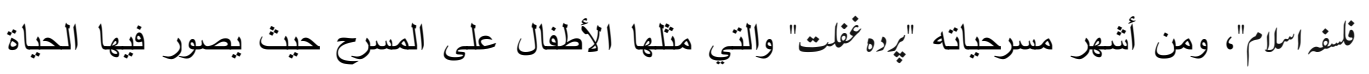

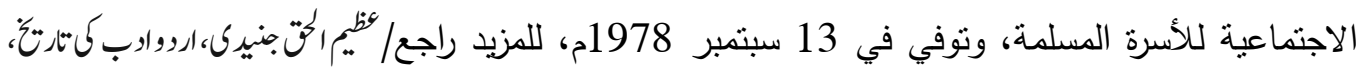

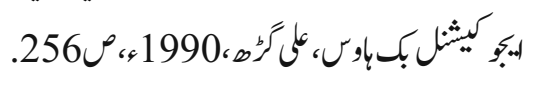




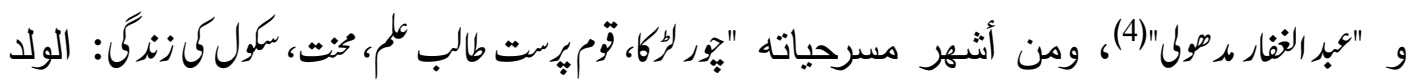
اللص، الطالب الوطني، الاجتهاد، الحياة المدرسية" عام 1937م، و "قيهزييك"، ومن أثنهر

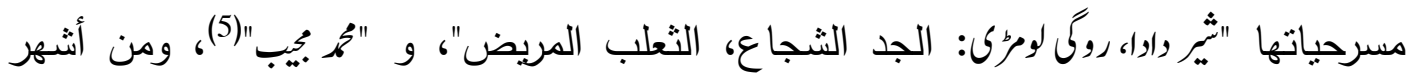
مسرحياته "آؤرُرال كري: هيا نمثل مسرحية" عام 1946م، وبعد ذلك بدأت سلسلة كتابة

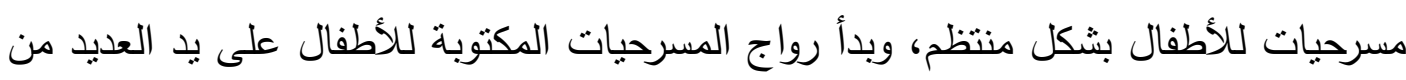
الأدباء (6) (1)

ولعل أهم ما امتازت به أغلب المسرحيات السالف ذكرها أنها لم تظل حبيسة الكتب

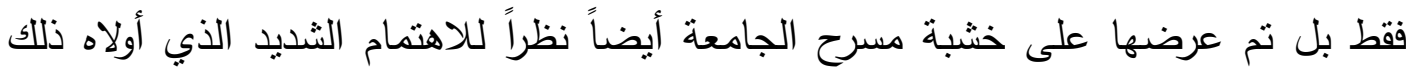

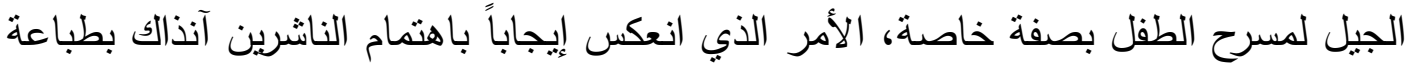
العديد من مسرحيات الأطفال(7). وعقب عام 1947م برزت أسماء العديد من الأدباء الذين ازدهر على أيديهم مسرح

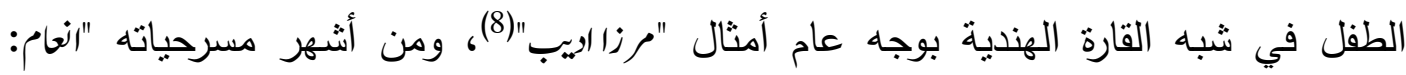

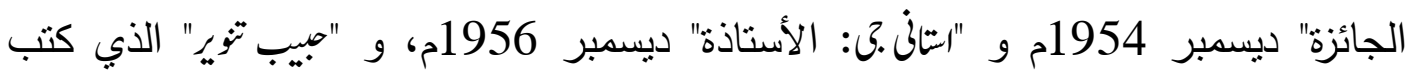

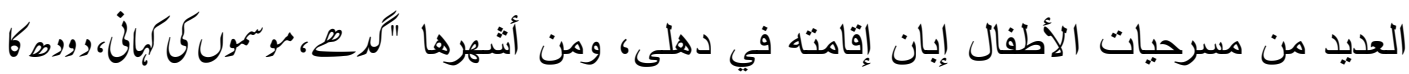
كال،، كرهابزار: الحمير ، قصة الفصول، كوب اللبن، سوق آجرا" عام 1954م، وفى ذات ذات الفنترة

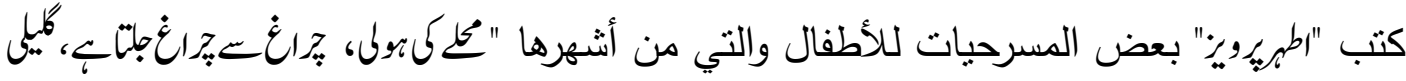

(4) عبد الغفار مدهولي: ولد عام 1908م، وعمل أستاذاً بالجامعة العلية الإسـامية، وكتب العديد من

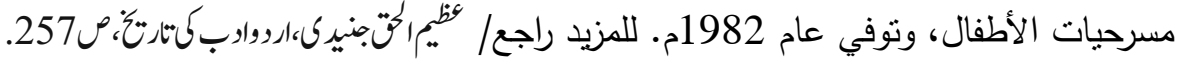

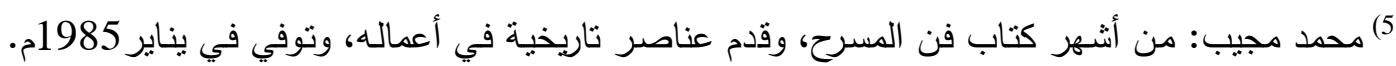

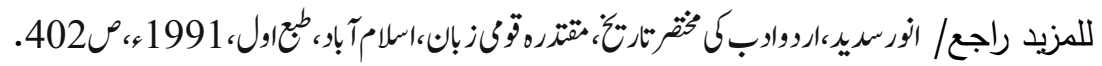

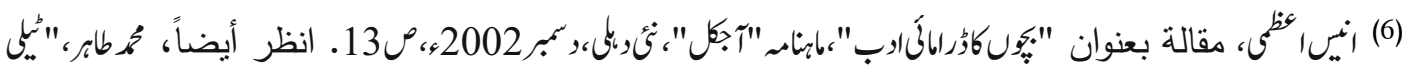

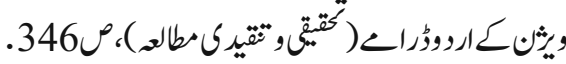

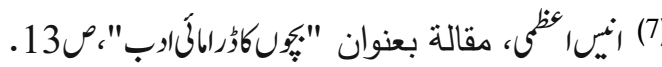

(8) مرزا اديب: ولد في 4 أبريل عام 1914م بمان بمدينة لاهور ، ويعد من الكتاب العظام والمترجمين أيضاً حيث

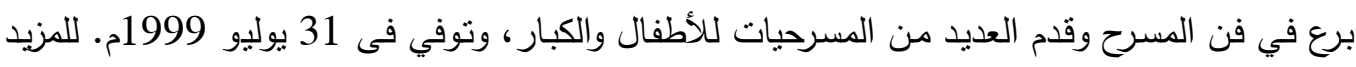

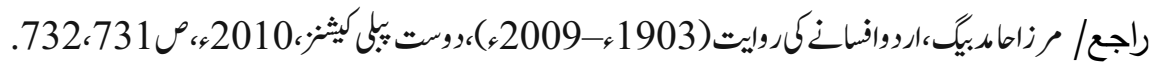




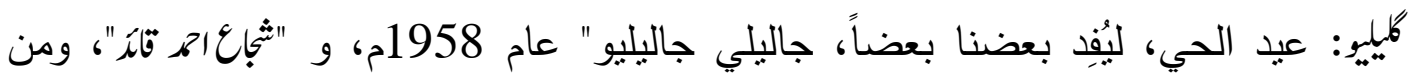

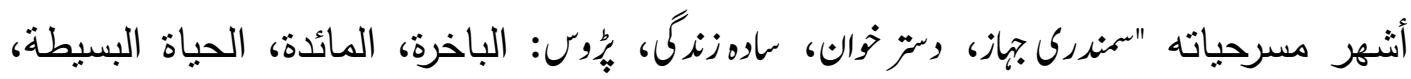

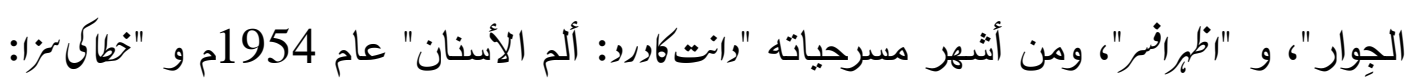

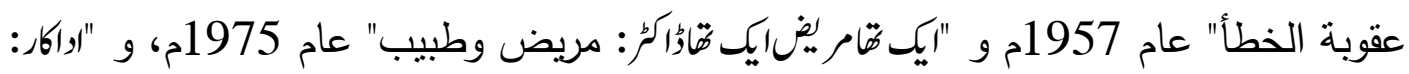

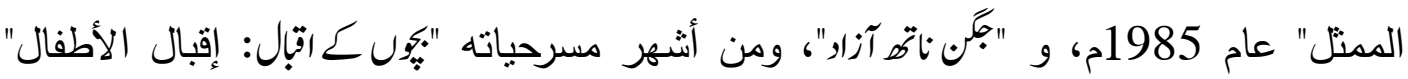

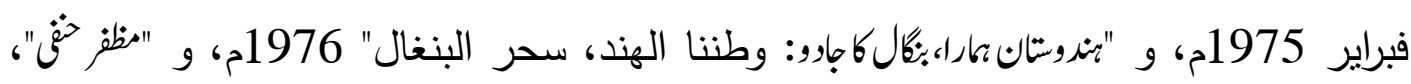

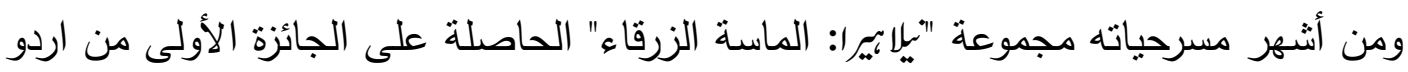

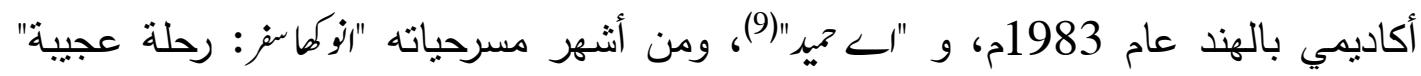
عام 1989م، و "عينك والاجن: جنى بالنظارة" 1993- 1996م، وغيرهم الكثير من الأدباء الذين أثروا هذا الفن بإبداعاتهم، بل زينوه بالعديد من الموضوعات العلمية الحديثة المناسبة لعصرنا الحاضر عصر العلوم والتكنولوجيا (10).

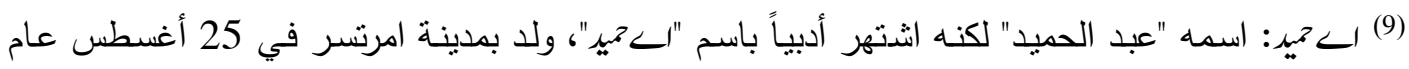

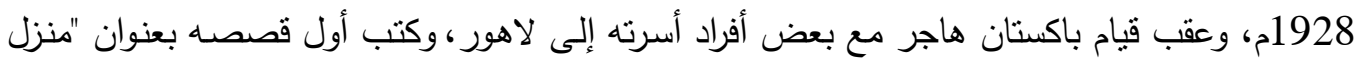

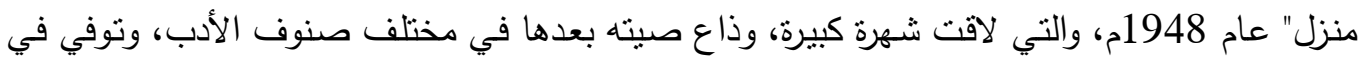

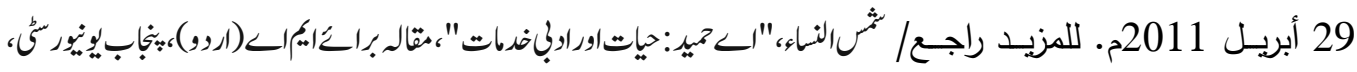

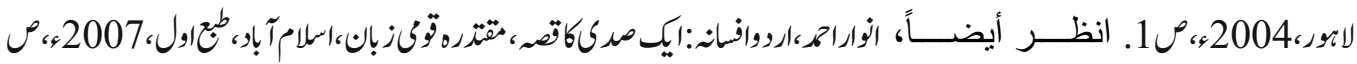

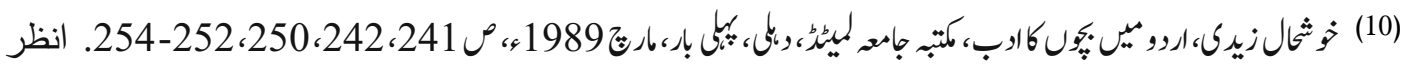

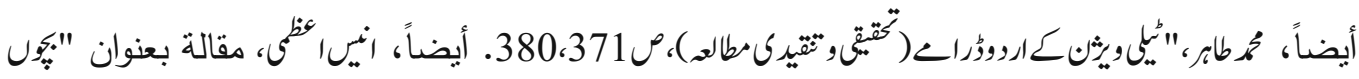

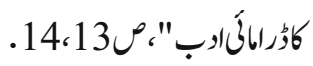




\section{المبحث الأول}

\section{"سيد نظر زيلدى: حياته وأعماله"}

1

يعد "سيد نظر زيدى" من أدباء الأردية المعاصرين الذين كتبوا في أدب الأطفال وساهموا فيه بحظ وافر، وقد ولد "زيدى" في أبريل عام 1917م في "بجنور" بالهند، واسمه

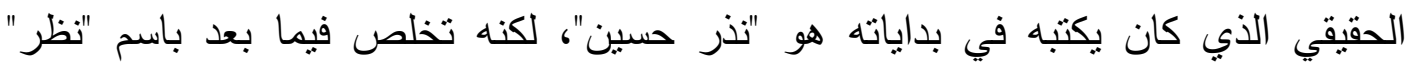
وعرف أدبياً باسم "نظر زيدى"، وارتبط اسمه بالعديد من الإدارات حيث عمل في البداية مع بع به

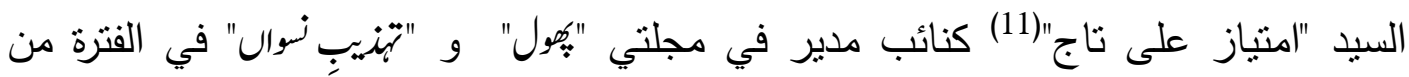
1947م حتى عام 1949م، وبعد ذلك عمل لمدة واحد وعشرين عاماً نائب مدير ثم مديراً لمجلة الأطفال الثهيرة "برايت" والتي كانت تصدر عن دار الكتب القومية بلاهور، ثم انتقل إلى راولبندي ضمن فريق إدارة صحيفة "تنير" في مايو 1971م حيث كتب فيها عدداً من بن الأعمدة الصحفية والمقالات الافتتاحية بشأن مختلف الموضوعات، وبعد ذلك عهر إليه بكتابة سلسلة كتب للأطفال بلغة سهلة وذات موضوعات إصلاحية مفيدة، فكانت فرصة ثمينة لنيل أعماله شهرة على الصعيد الأدبي، وفى عام 1979م عمل نائب مدير مجلة "اروورُاجُشت" حتى عام 1981م، وفى عام 1982م عمل كباحث في إدارة المعارف الإسلامية حتى تركها نظراً لاعتلال صحته عام 1992م، وتوفي في لاهور في 21 يونيو عام 2002م (12). تمتع "زيدى" بشخصية مخلصة ومحبة للآخرين، الأمر الذي انعكس جلياً في أدبه الإصلاحي الذي اتخذه وسيلة لتقديم الأفكار والخصال الحسنة للأطفال من الثغف بتحصيل

(11) امنياز علي تاج: ولد عام 1900م بمنطقة "نياز مندان" بمدينة لاهور، وبرع في فن الفكاهة والمزاح

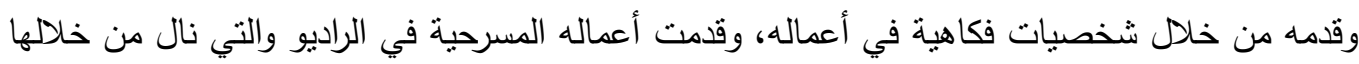

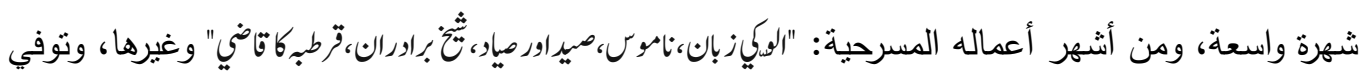

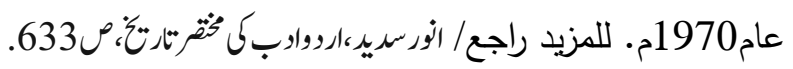

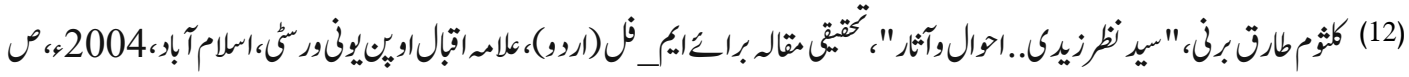

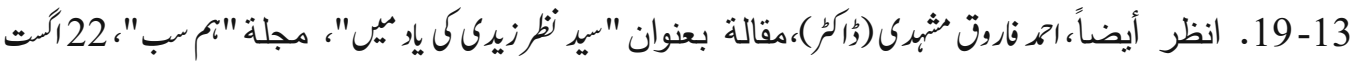

https://www.humsub.com.pk/339553/dr-ahmad-farooq-mashhadi-10/ 
العلم، والاجتهاد في طلبه على الدوام، وعلو الهمة، وغيرها. ونظراً لإسهاماته المتميزة في مجال أدب الأطفال حصل كتابه "سب ــرُانسان: أعظم إنسان" على الجائزة الرئاسية للتميز

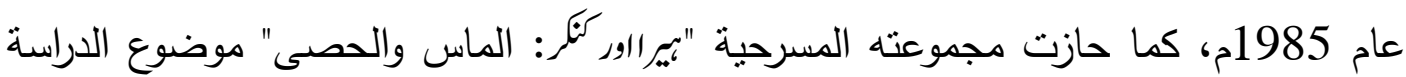
على جائزة أفضل عمل درامي للأطفال من قبل المجلس القومي للكتاب عام 2002مجام (13). كتب "زيدى" في مختلف صنوف الأدب من قصة ورواية ومسرح وشعر وسيرة ذاتية،

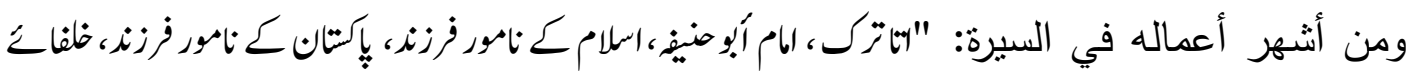

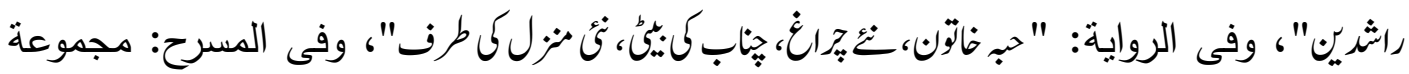

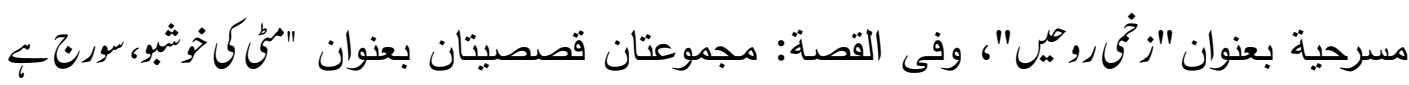

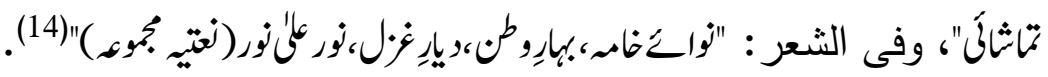
أما في مجال أدب الأطفال فقد تتوعت أعماله أيضاً ما بين شعر ومسرح ورواية لهارية ومجموعات قصصية، ومن أشهرها في الشعر : مجموعتان شعريتان بعنوان "مهمت يهول"يناير

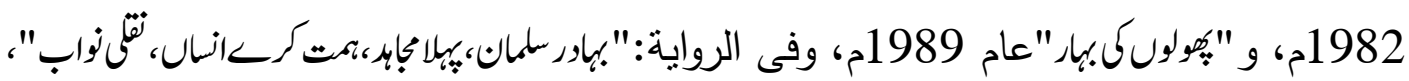

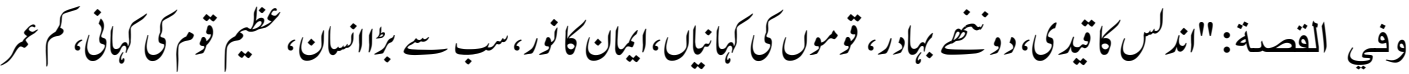

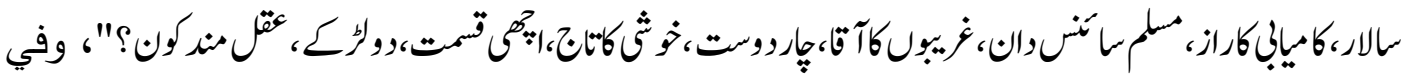
المسرح: مجموعات مسرحية بعنوان "سونـ ثئول" مارس 1981م وتضم أربع مسرحيات، و

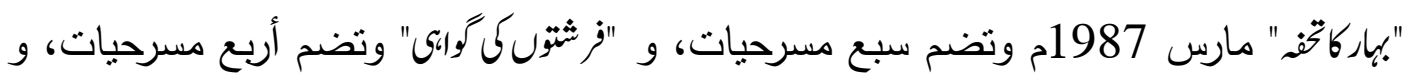

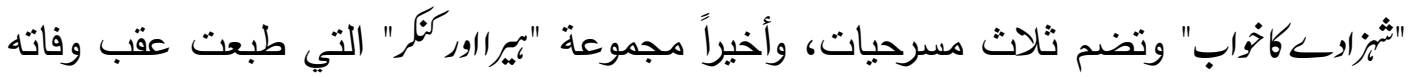
عام 2003م وتضم أربع مسرحيات(15).

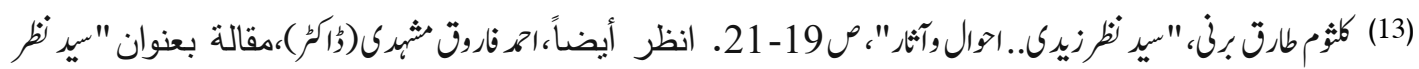

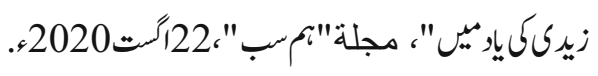

https://www.humsub.com.pk/339553/dr-ahmad-farooq-mashhadi-10/

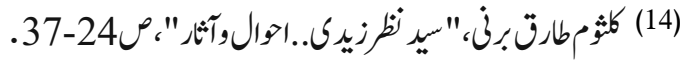

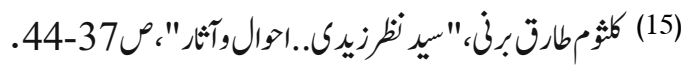




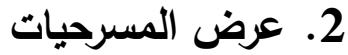

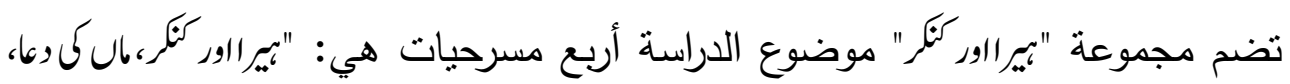

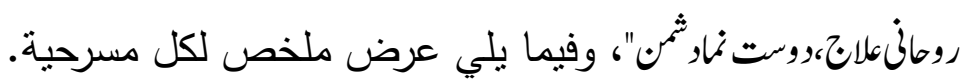

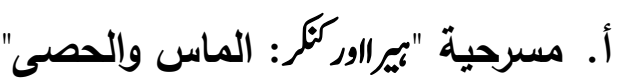

شخوصها سبعة، ومشاهدها خمسة، وتدور أحداثها حول قيمة أساسية هي العلم والحرص على تحصيله بكل جدية وهمة عالية مهما كانت العوائق والتحديات من خال ولد مثالي يدعى "عثمان" يبلغ من العمر ثلاثة عشر عاماً يجلس في حجرته منكباً على طاولته منهمكاً بجدية في أداء واجباته الددرسية، بينما يدخل عليه المشاغبان أخوه "ساجد" وابن خالته

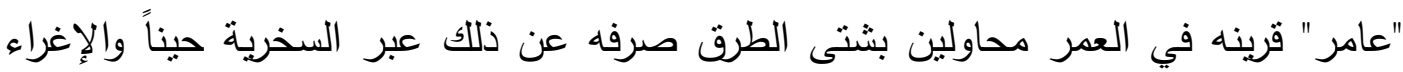

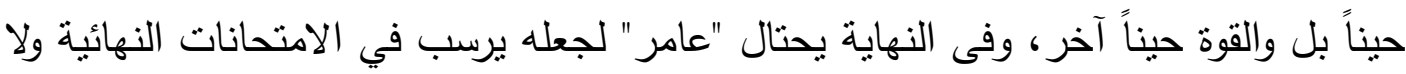

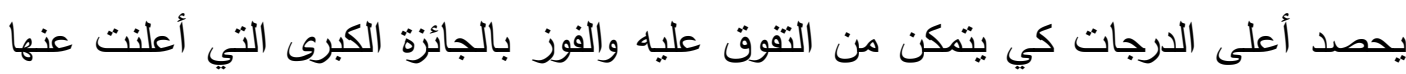

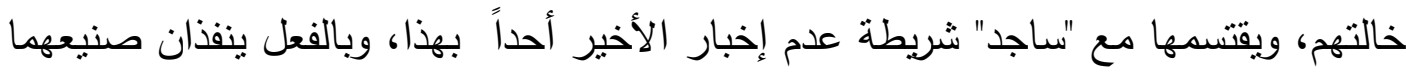

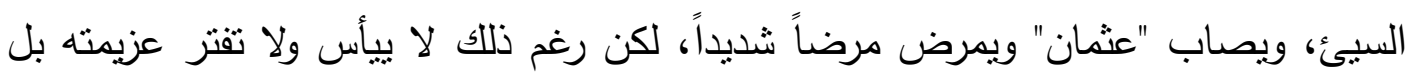

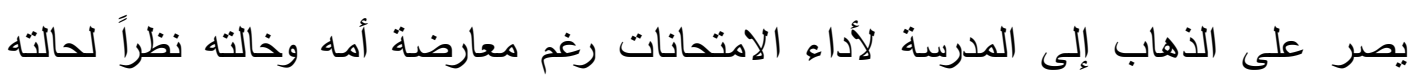
الصحية وخشية ازدياد مرضه، لكنهما في النهاية يوافقان على مطلبه الأمر الذى يصيب كلا لالها

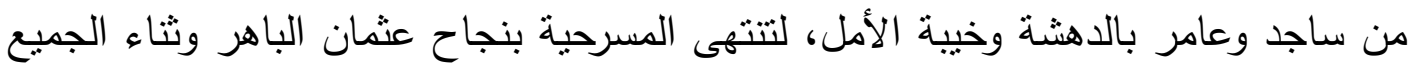
عليه في حفل المدرسة وفوزه بجائزة خالته وسط تصفيق الجميع ومباركتهم له.

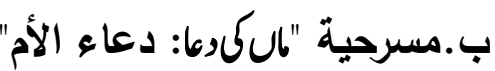

شخوصها ستة، ومشاهدها ثلاثة، وتدور أحداثها حول قيمة أساسية هي طاعة الوالدين وبيان فضل دعاء الأم ووقايته الابن من مصارع السوء من خلال ولد يدعى "روشى"

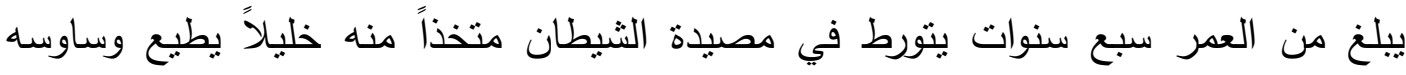
ويعصي والديه، لارجة أن الثيطان ينحدى ملك الحسنات بشأن فئن مآله السيئ وعاقبته الوخيمة التي ينوعد بأن تصل إلى اعتقاله والزج به في غياهب السجن بل وحتى إعدامه، فيكون بذللك

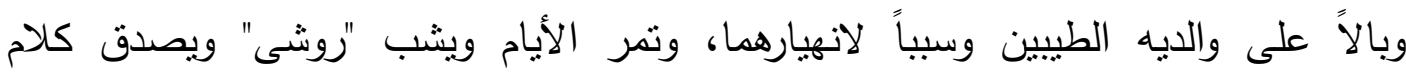

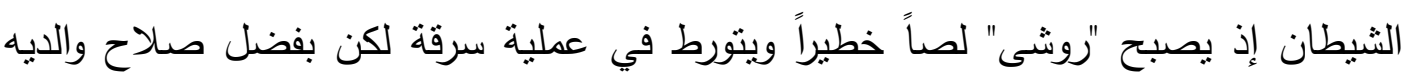


ودعاء أمه المتواصل له بالهداية وصلاح الحال والمآل يتقبل الله منها ويتحول حال الولد من

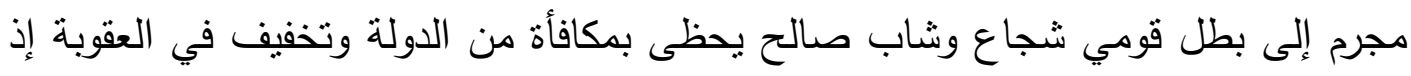

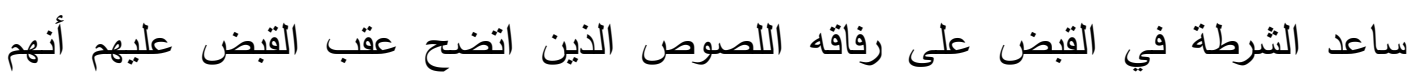

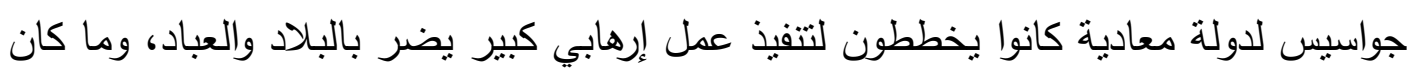

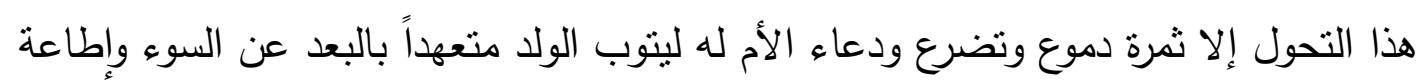
والديه وإسعادهما.

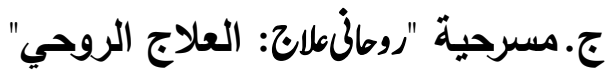

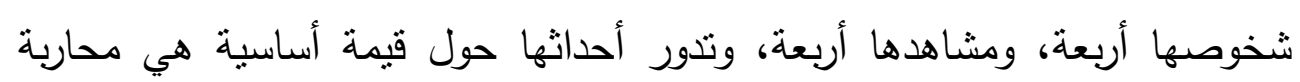

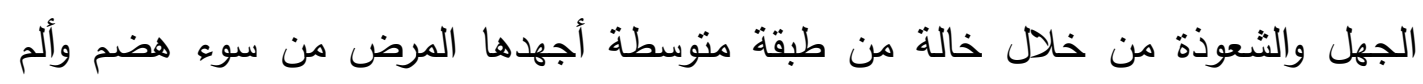

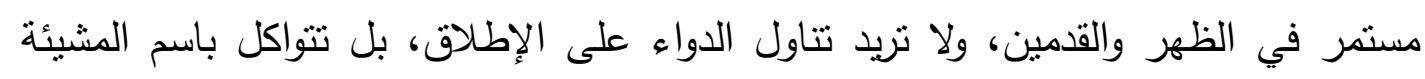

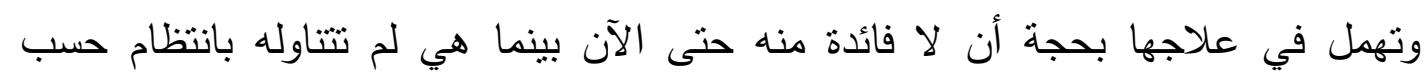

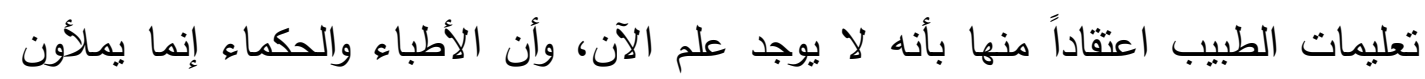

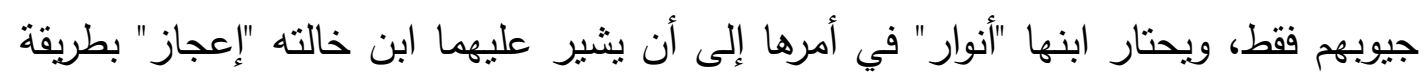

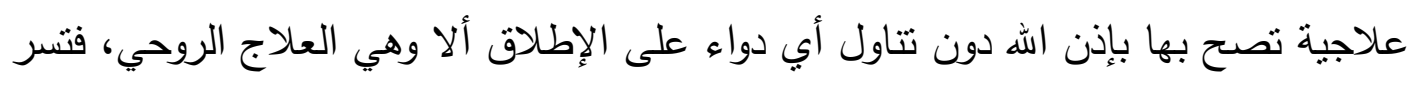

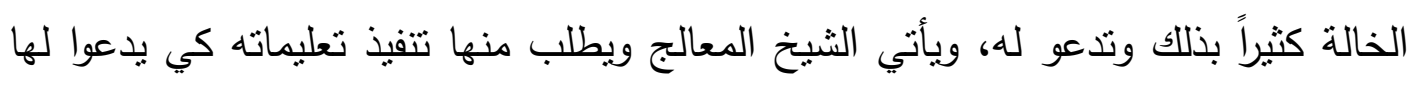

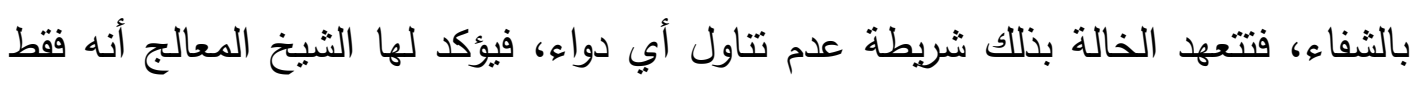

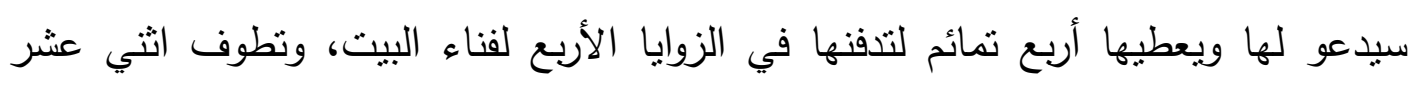

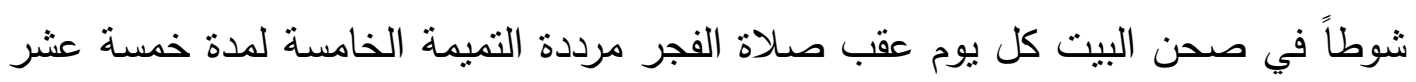

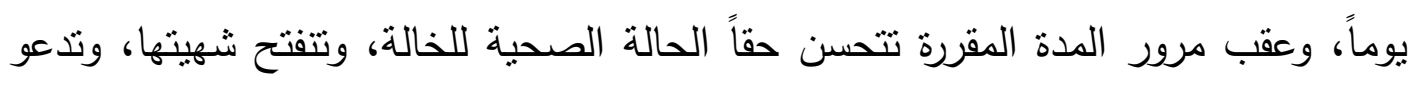

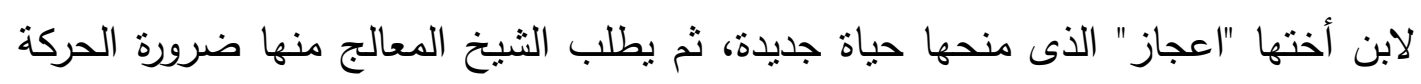

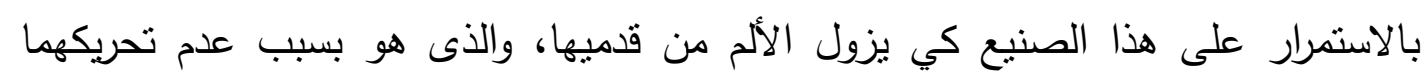

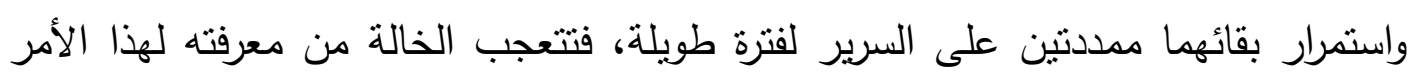

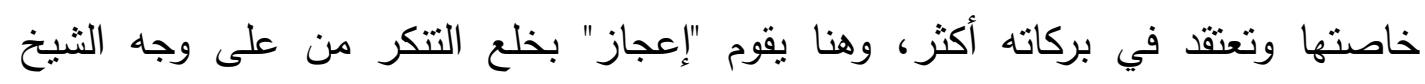

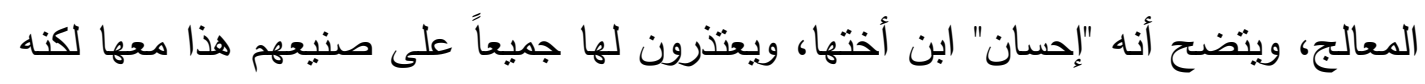
من أجل صحتها. 


\section{د. مسرحية "روست نمارثمث: عدو كصديق"}

شخوصها ستة، ومشاهدها خمسة، وتدور أحداثها حول قيمة أساسية هي الاتحاد قوة والفرقة ضعف، من خلال عجوز وأربع أخوة يرتدى كل منهم حلة تشير إلى أحد أقاليم باكستان الأربعة، وقد نجحوا بفضل اتحادهم في امتلاك أراضي قريتهم وبيوتها لكنهم يريدون تقسيم هذه الممتلكات فيما بينهم بحجة عدم مساواة الكسول بالمجتهد، فنتاجروا بالأيدي مع

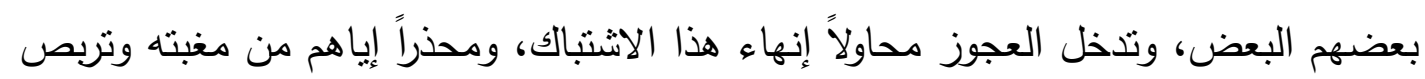
عدوهم بهم، ومعتبراً إياه انتحاراً لهم، في تلك الأثتاء يدخل عليهم التاجر الهندوسي مبنسماً

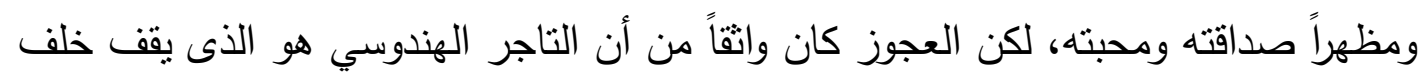
هذه الأنانية التي سمدت أذهان أبنائه نظراً لإرادته الخفية الاستيلاء على هذه الأرض وتلك انك البيوت التي امتلكوها، وبالفعل يشرع في استقطاب كل واحد منهم على حدة مسماً أفكاره تجاه العجوز وإخوانه الآخرين حتى يتقاتلوا ويصيبوا بعضهم البعض بإصابات بالغة، فيأسف العجوز لرؤيتهم هكذا وبيين لهم عدوهم الحقيقي الذى أغدق عليهح السلاح والأموال والأفكار المسمومة ليفعلوا بأنفسهم هكذا، وبالتالي ينجح في الاستيلاء على ممتلكاتهم بسهولة والتي

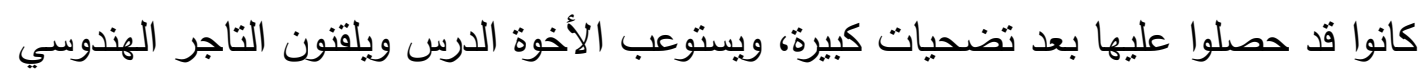
درساً لا ينساه، ويتعانقون ممسكين بأيدي بعضهم رمزاً للوحدة والإخاء. 


\section{المبحث الثاني \\ القيم التريوية في مجموعة "ايمراوركتر"}

ترتبط القيم بالحاجات الأساسية للإنسان، وقد يعبر عنها بشكل مباشر، وقد تكون ضمنية تختفي في السلوك والتصرفات، وتترتب وفق أفضليتها ومستوى أهميتها وتقديرها، ولما كانت القيم السائدة في مجتمع من المجتمعات هي معيار تحركه نحو أهدافه، وهي المقياس الذي يزن له بكل دقة أموره واتجاهاته، فإن المجتمعات تحتاج إلى القيم التربوية التي تأخذ بيدها من أجل مواجهة تحديات العصر، وتخلق منها المواطن الصالح الذي يتمسك بتراثه ويحميه، وتحدد أهدافه وسلوكه الاجتماعي (16)، فالطفل يولد وهو خالٍ من المعايير والقيم التي لهي توجه سلوكه تجاه غيره، وتقوم المؤسسات التربوية داخل المجتمع الذي يعيش فيه بإكسابه هذه

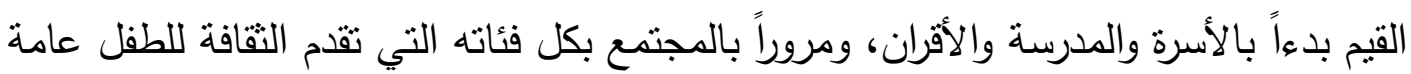

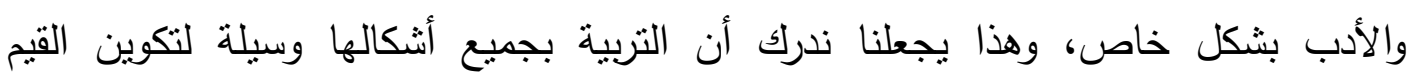
وتعديلها (17).

وتعرف القيم التربوية على أنها "كل صفة ذات أهمية لاعتبارات نفسية أو اجتماعية

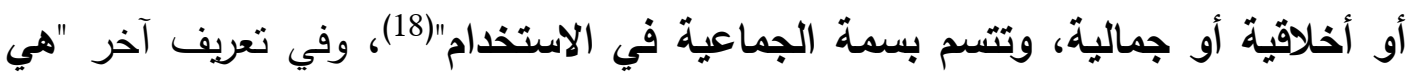
مقياس أو معيار للحكم على الثيء باعتباره مرغويًا فيه أو مرغويًا عنه، وهي الأساس في اهي تكوين الأهداف على اعتبار أن الهدف هو ما يطمح إليه الفرد ذاتيًا بصورة مباشرة أو غير

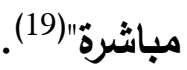

وقد نجح الأديب في بث العديد من القيم التربوية للطفل، وحرص على أن يأتي بجزء منها بشكل مباشر صريح، وبجزء آخر بشكل ضمني مصاحب، لكي تتمي شخصية الطفل وتصقلها، وتشهم مساهمة واضحة في تكوين شخصيته الثاملة وتتميتها فكريًا وتقافيًا ودينيًا وخلقيًا واجتماعيًا، فتجعل منه إنساناً سوياً ذا عقلية مستتيرة بين أفراد المجتمع. وانئ

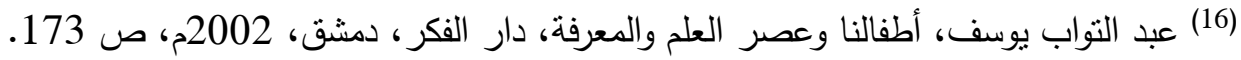

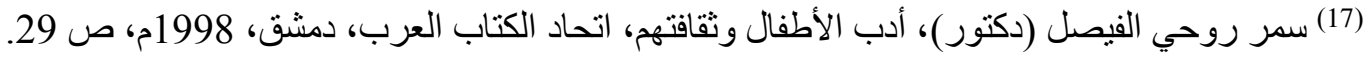

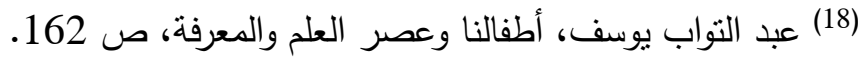
(19) محمد صوالحة، دراسة تحليلية لواقع القيم في عينة من قصص الأطفال، مجلة اتحاد الجامعات العربية

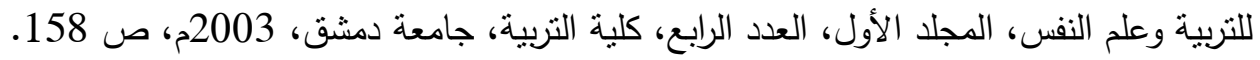


ولما كان هدف المبحث هو التعرف على مدى توافر القيم التربوية في المجموعة المسرحية "يمراور كنكر"، وإبراز القيم التربوية المتوفرة، فسيكون هذا من خلال التحليل التتبعي القيمي باستخدام -مقياس القيم لـ "أحمد كنعان" عام 1995م ـ (20) طبقاً للجدول الآتي:

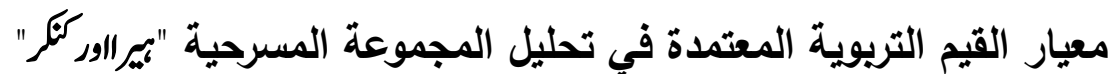

\begin{tabular}{|c|c|c|}
\hline محاور القيمة & نوع القيمة & م \\
\hline 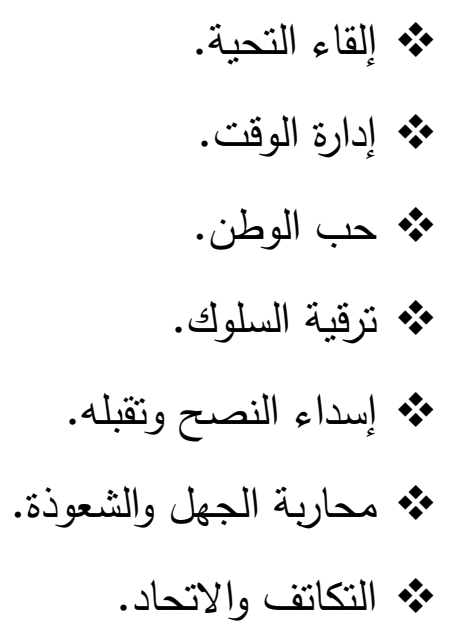 & الاجتماعية & 1 \\
\hline 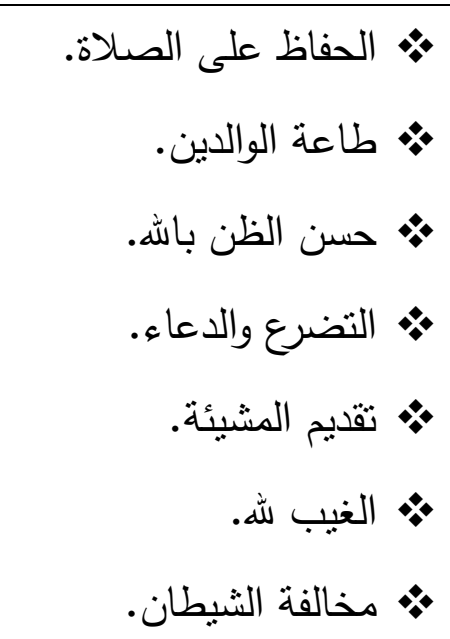 & الاينية & 2 \\
\hline 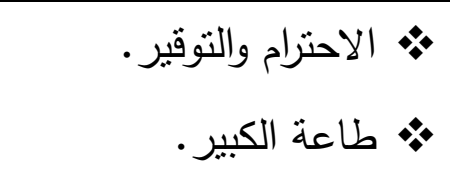 & الأخلاقية & 3 \\
\hline
\end{tabular}

(20) أحمد علي كنعان (دكتور)، أدب الأطفال والقيم التربوية، دار الفكر المعاصر، الطبعة الأولى، القاهرة، 1995م، ص 120. 


\begin{tabular}{|c|c|c|}
\hline 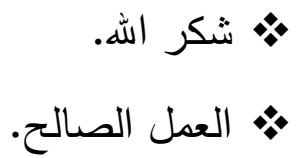 & & \\
\hline * العلم. & المعرفية & 4 \\
\hline
\end{tabular}

وفيما يلي تحليل القيم التربوية الواردة في المجموعة المسرحية موضوع الدراسة.

أولاً: القيم الاجتماعية

إلقاء التحية الاجنماعه

يغرس الأديب قيمة إلقاء التحية في نفوس الأطفال من خلال إلقاء تحية الإسلام وهي

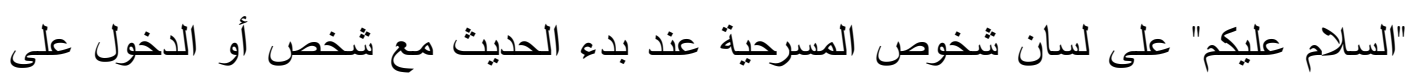
جماعة، خاصة وأنهم يعيشون في دولة قامت في حقيقتها على أساس الدين كوطن مستقل لمسلمي شبه القارة الهندية، وبالتالي فأغلب سكانها من المسلمين. وهذا مطابق لتعاليم الدين

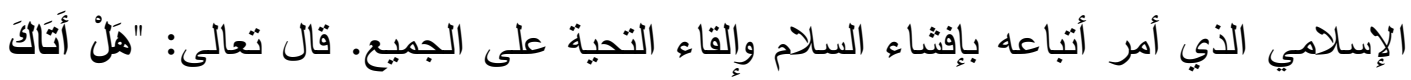

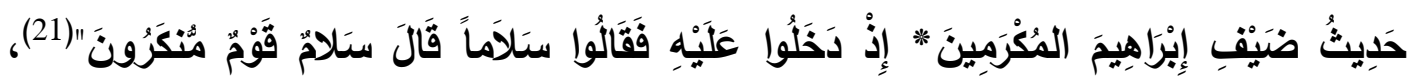

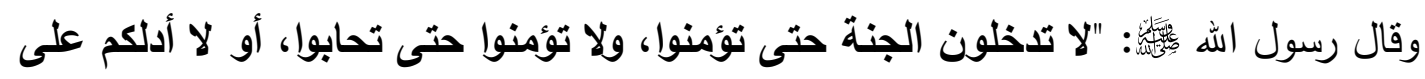

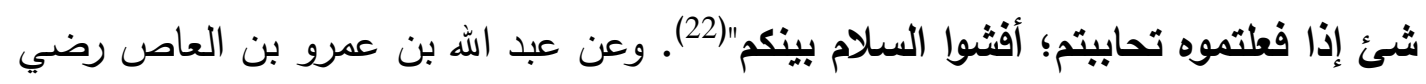
الله عنهما أن رجلاً سأل النبي بـ من عرفت ومن لم تعرف"(23). وغيرها من الأحاديث الكثيرة التي تحث على إلقاء التحية، تلك الكا القيمة التي أراد الأديب التأكيد عليها وغرسها في نفوس الأطفال من خلال المسرحيات موضوع الدراسة.

ففي مسرحية "روست نمارثم: عدو كصديق" يقول الثاب البنجابي عندما يدخل على

العجوز : "الثاب الأول: السلام عليكم بابا! العجوز : وعليكم السلام، وعليكم السلام"(24).

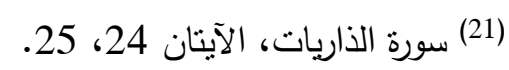

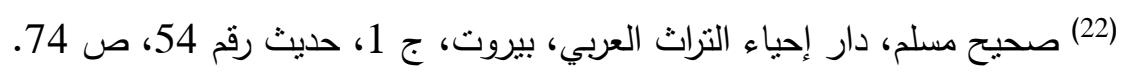

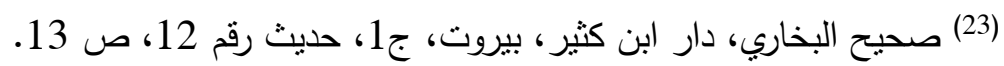

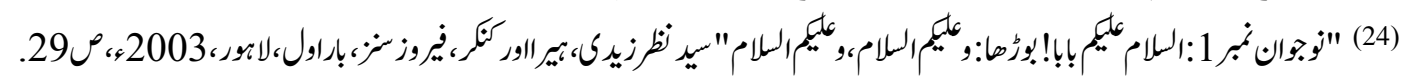


وفي موضع آخر من المسرحية ذاتها يقول الأديب:

"يلخل ثلاثنة شبان ويلقون السلام بصوت مفعم بالحيوية...........

العجوز : (سعيداً للغاية) وعليكم السلام، وعليكم السلام"(25).

وفى مسرحية "الكموعا: دعاء الأم" يقول "روشى" عندما يدخل البيت:

"روشى: السلام عليكم أمى الحبيبة!

الأم: (بحب) وعليكم السلام يا ولدى، وعليكم الديم السلام" (26).

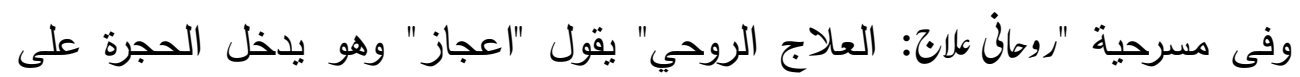

خالته: "اعجاز: السلام عليكم خالتي الحبيبة!

الخالة: (ترفع رأسها محدةة) من؟ اعجاز ! وعليكم السلام، تعال يا بني"(27.).

من هنا نرى مدى اهتمام الأديب بتلك القيمة والتي استخدمها في أغلب مسرحياته موضوع الدراسة وفي أكثر من موضع فيها، ليرسخها في أذهان الأطفال كي يعتادوا عليها، فيتأدبون بالخلق الحسن القويم، وقد جاءت كقيمة مصاحبة بأسلوب مباشر في جميع المسرحيات.

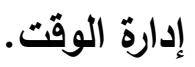

الوقت هو أحد الأمور الثمينة في هذه الحياة؛ لأنه الوحيد الذي إذا ذهب فلا يمكن

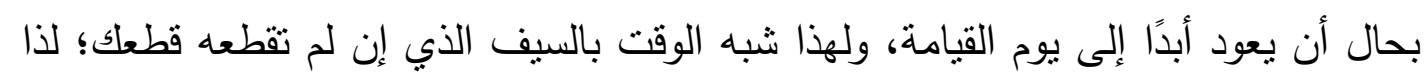

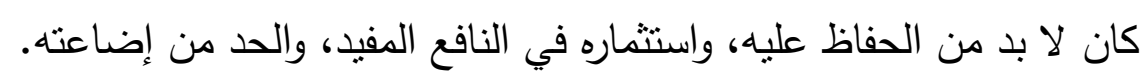

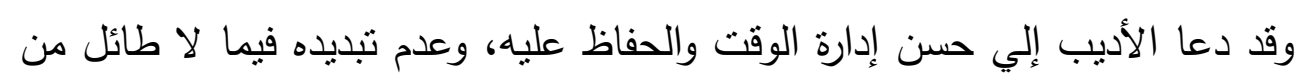

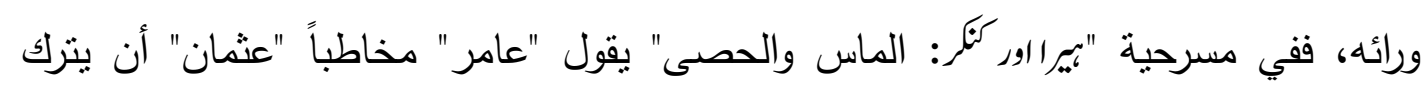
مذاكرته ويخرج للهو معهم: مئه

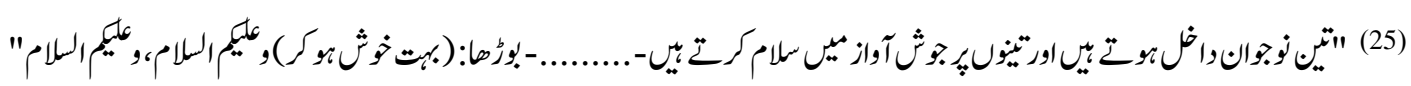

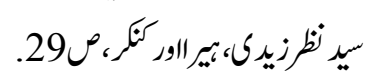

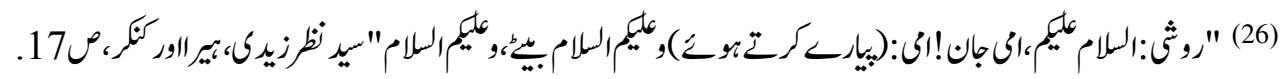

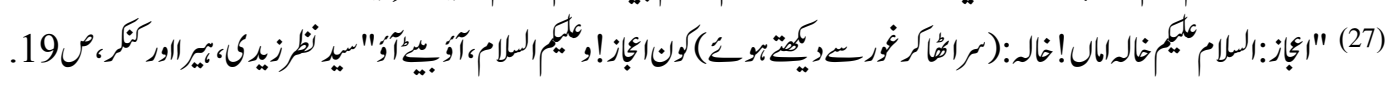


"عامر: (ممسكاً بذراع عثمان ليوقفه) لقد ذاكرت كثيراً أخي العزيز، فارحم هذه الكتب الآن وتعال معنا، فوالله لقد أعددثُ برنامجاً رائعًا للغاية. عثمان: (مخلِّصًا ذراعه) أخي عامر! لا تزعجني، فإني أقوم بعمل ضروري جذاً

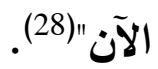
وفي موضع آخر من المسرحية ذاتها يقول "عثمان" مخاطباً "عامر" الذي يلح عليه بشدة لأجل نرك مذاكرته وواجباته والخروج معهم: "عثمان: دعني أعمل أيها الأخ المحترم العزيز، فسأنهي عملي ثم أثاهد الانيا الجميلة أيضاً"(29).

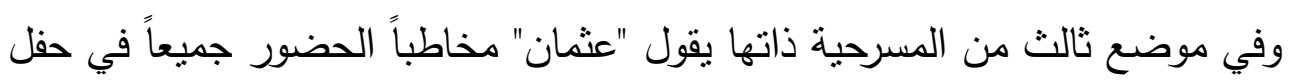
تقوقه متحدثًا عن سر تقوقه الباهر ، وكيف أن والديه وأساتذته نصحوه بتقدير الوقت : "عثمان: الحضور الكريم! سأخبركم عن سر نجاحي باختصار حفاظاً على وقت حضراتكم الثمين.............. ونصحوني بوجوب تقدير الوقت"(30). وهكذا أورد الأديب هذه القيمة في أكثر من موضع في المسرحية تأكيداً على أهميتها، وقد جاءت كقيمة مصاحبة بأسلوب مباشر . * خب الوطن. أبرز الأديب قيمة حب الوطن كقيمة مصاحبة في أكثر من موضع، بل إنه جسد هذا الحب والانتماء تجسيداً عملياً ليخرج بالطفل من عالم الأقوال إلى عالم الأفعال والأعمال والتضحيات من أجل أمن هذا الوطن وسلامته. ففي مسرحية "الكموعا: دعاء الأم" يحكي "روشى" لوالديه كيف تحول من مجرم إلى هن بطل قومي فيقول: "روشى: ......... وشعرت أن العمل الذي سنقوم به سيسبب ضراً

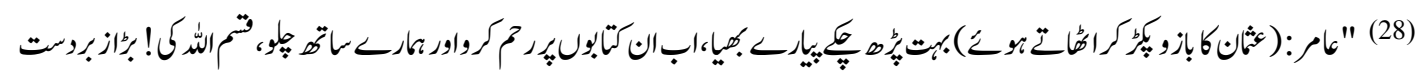

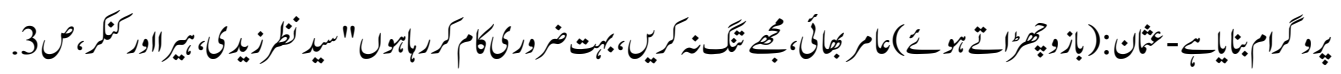

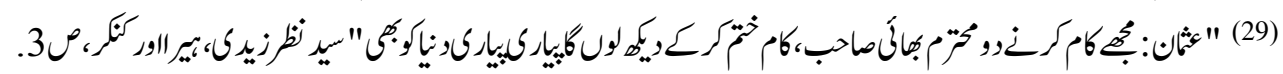

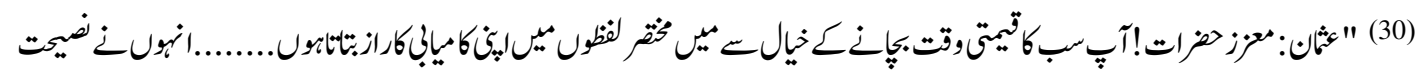

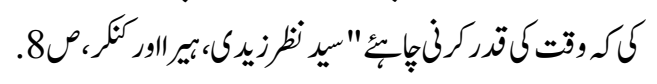


كبيراً جداً لبلدنا وأمتنا، فاختلفت مع رفاقي دون الاكتراث بحياتي، وقلت لهم إنني لن أقوم بهذا العمل بنفسي ولن أسمح لكم بالقيام به" (31).

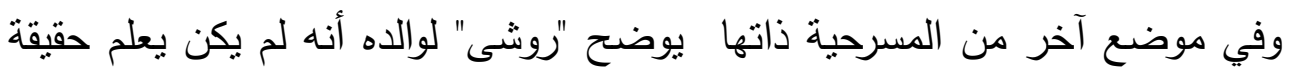

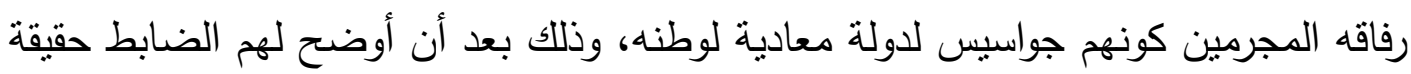

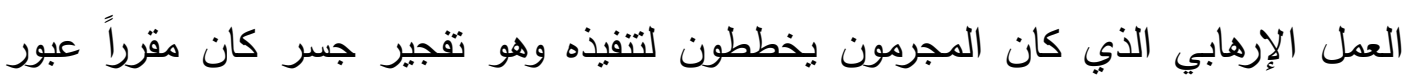

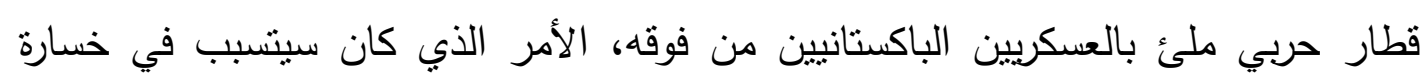

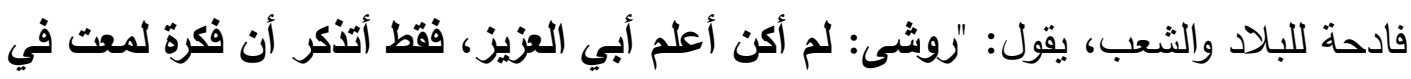

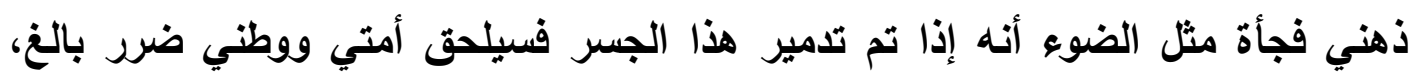
فبدأت أنثتبك معهم، وقتت لن أسمح بتدمير هذا الجسر "(32).

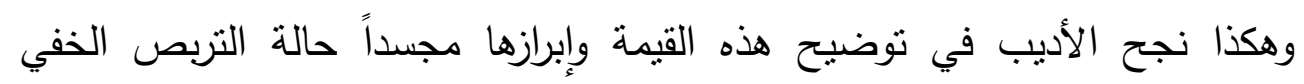

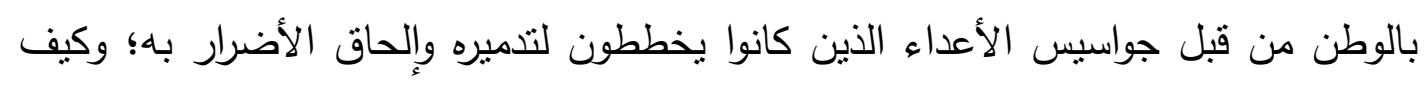

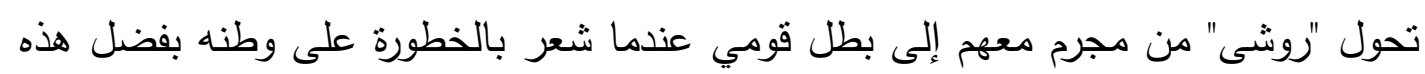
القيمة المغروسة لديه، فهذه القيمة تدعو إلي تكوين المعايير والعادات والاتجاهات الصحيحة الصيحة

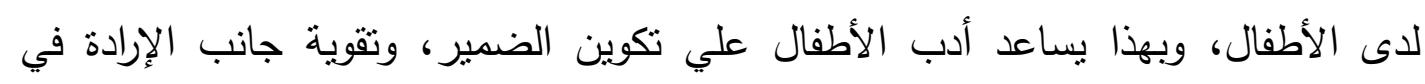

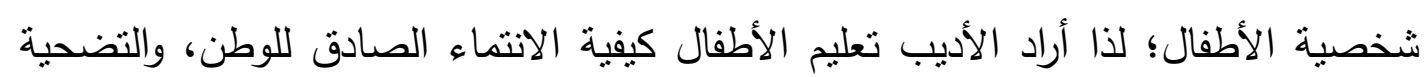
من أجله ولو بالروح من أجل بقائه وسلامته.

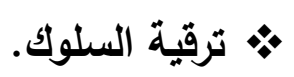

حث الأديب على تحسين وترقية السلوك لدى الطفل كي يخرج إلى المجتمع فرداً

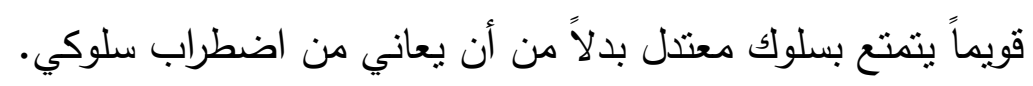

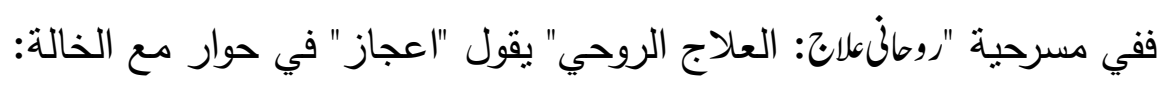

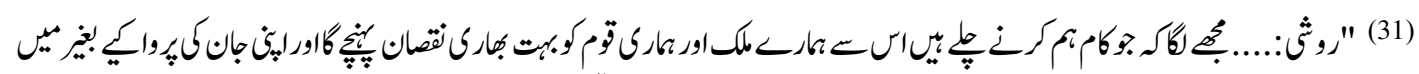

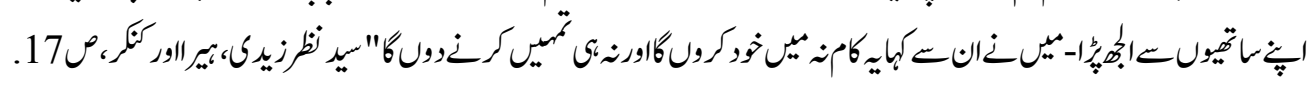

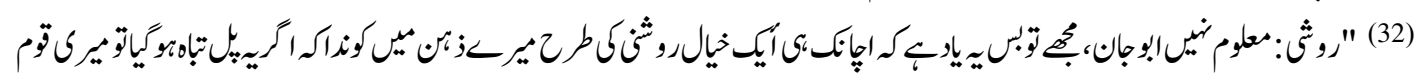

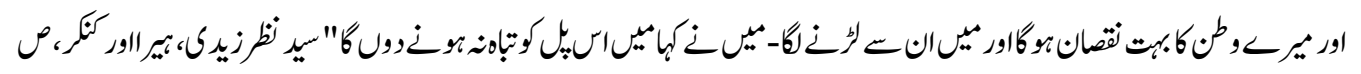


"إعجاز: ........ بالنظر إلى زحام السيارات في الثوارع يبدو ما شاء الله أن باكستان قـ أضحت أغنى دولة في العالم.

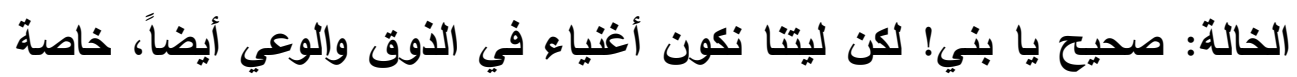

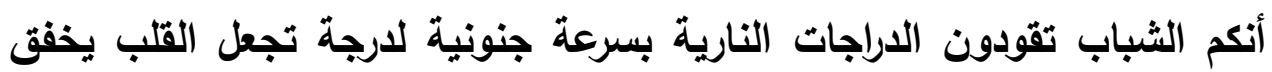

$$
\text { بشدة. }
$$

إعجاز: (يمسح وجهه بمنديل) أنت محقة، فقد تعقدت كثيراً مشكلة شباب البلد،

ويبدو أنهم يركضون من أجل التقام على بعضهم البعض في سوء الأدب"(33).

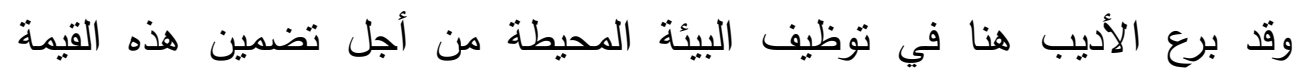

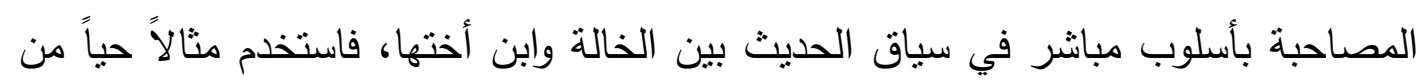

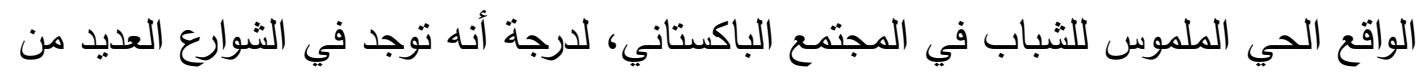

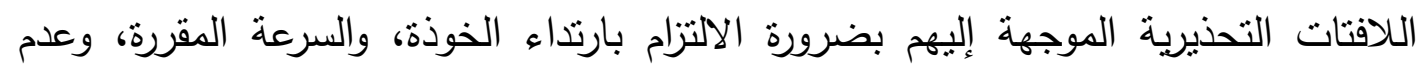

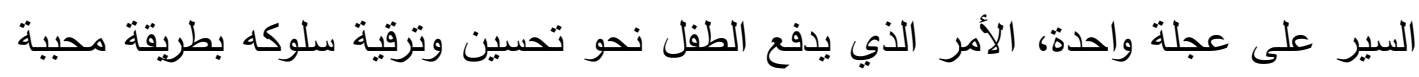

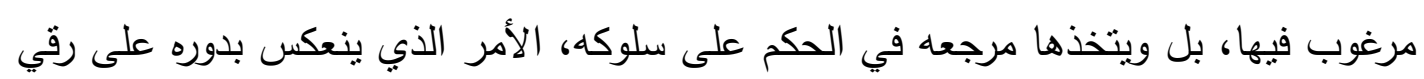

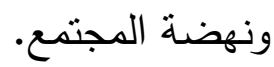

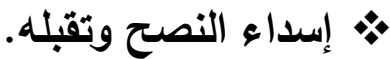

حث الأديب كذلك على قيمة أخرى مهمة للأطفال ألا وهي إسداء النصح للآخرين،

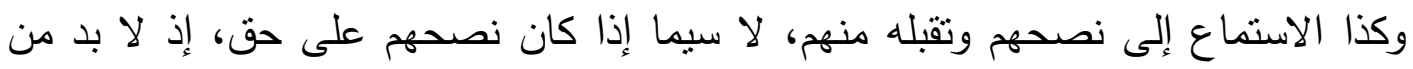

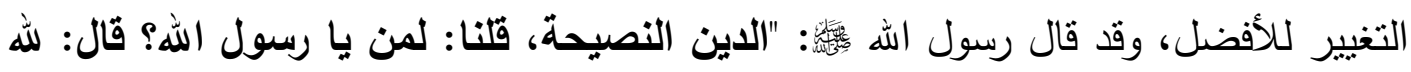
ولكتابه ولرسوله ولأأمة المسلمين وعامتهر" (34).

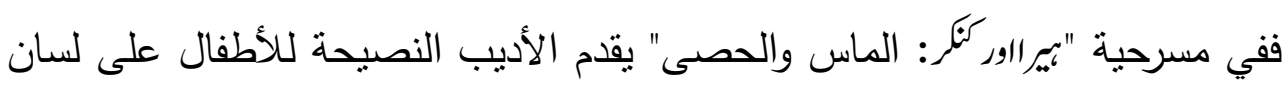

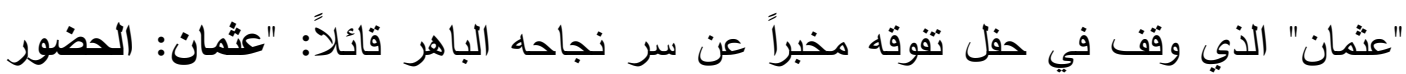

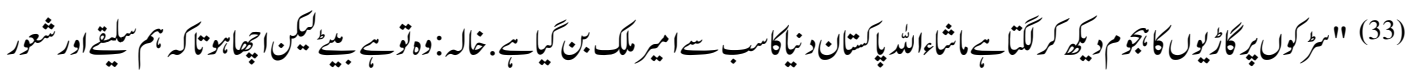

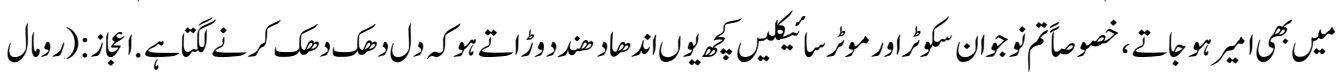

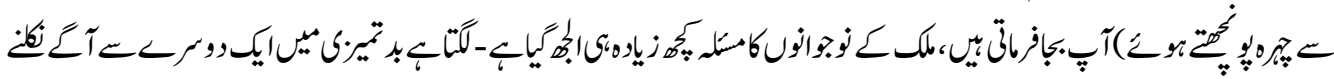

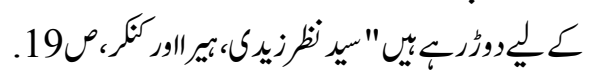

ا 
الكريم! سأخبركم عن سر نجاحي باختصار حفاظاً على وقت حضراتكم الثمين وهو أني

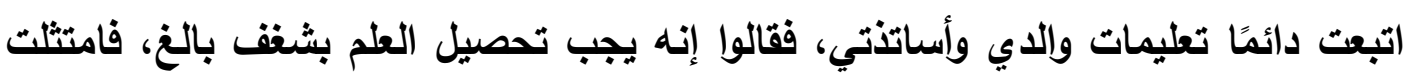
أمرهم هذا بإخلاص واجتهدت كثيراً من أجل تحصيل العلم، ونصحوني بوجوب تقدير الوقت، ووجوب احترام الكبار، ووجوب تجنب الأمور السيئة، والآخراط في الأعمال الصالحة، والمحافظة على نقاء ذهني وأفكاري، فقعلت هذه الأمور جميعها فوفقتي الله تعالى بفضله، وأقول لكل أصدقائي أن يتبنوا أيضاً هذا النهج ذاته، وسيحققون نجاحاً أكثر مني إن شاء أشهاء الله"(35).

وفي مسرحية "الككوعا: دعاء الأم" يقدم الأديب النصيحة للأطفال على لسان ضابط

الثرطة قائلاً: "ضابط الشرطة: يا بني! لا بـ مع التوية أيضاً ألا تغضب والديك أبداً"(36).

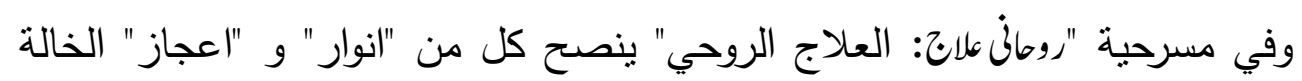
بضرورة الأخذ بالأسباب من خلا تناول الدواء وبانتظام أيضاً كي يزول ألمها: "أنوار : (بجدية) الأمر ليس كذلك أخي إعجاز ، إنها مشكلة دواء أمي العزيزة.

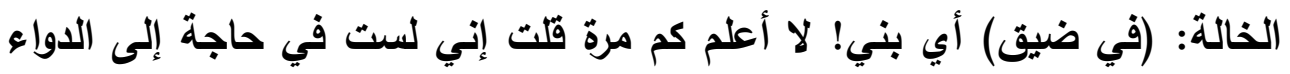

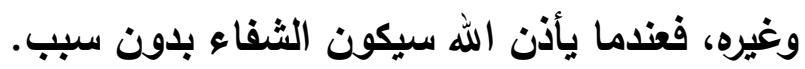

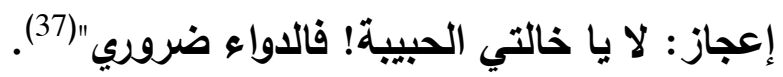

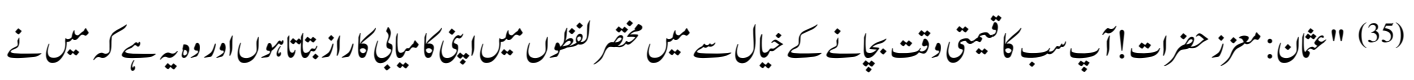

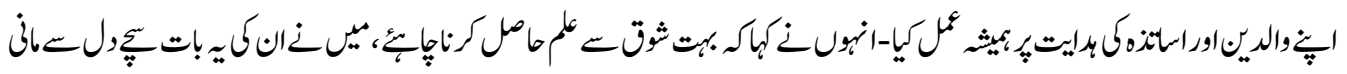

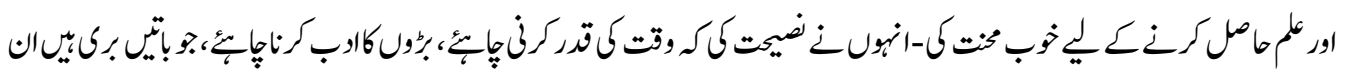

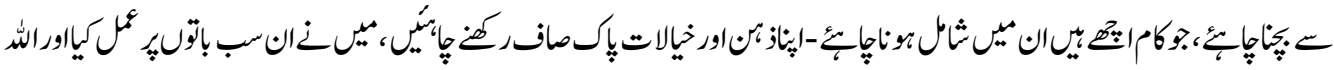

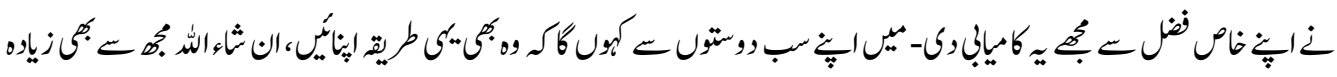

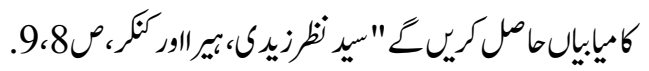

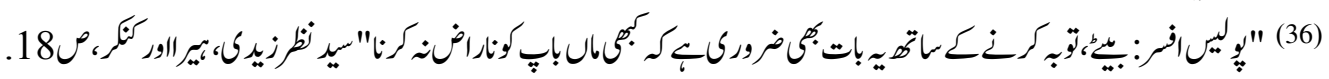

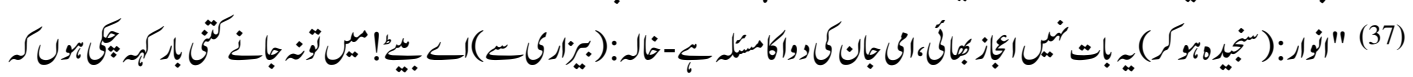

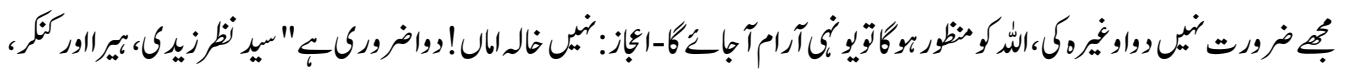
ص.20 
وتتمادى الخالة في رفضها النصيحة منظاهرة أنها بخير، وأن ابنها بقلق عبثاً، فينصحها "انوار" عبر بيان حالها بضرورة الاهتمام بصحتها وتتاول الدواء بانتظام كي يؤتي

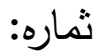
"أنوار: لا أقلق عبثاً أمي العزيزة، فأنت لا تهتمين بنفكك، ولا تتناولين الدواء

بانتظام. الخالة: إن بلت أي فائدة فسأتناوله، .......... بأن

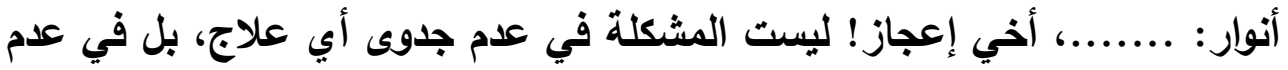
تناول أمي العزيزة الدواء بانتظام"(38).

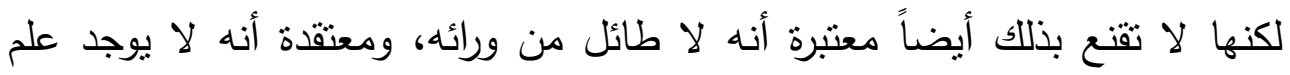
الآن، وأن الأطباء والحكماء إنما يملأون جيوبهم فقط، فتقول مصرة على عدم تقبل النصيحة: "الخالة: ....... لقد قلت إني لن أتناول الدواء"(39).

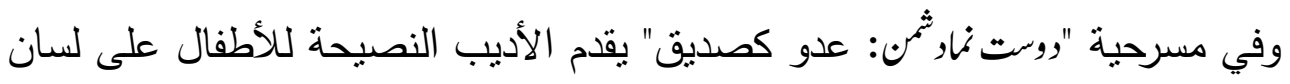
العجوز قائلاً: "تذكروا، إن عدوكم الآن بالمرصاد لكم، فإذا تثثاجرتم مع بعضكم فستدمرون الإبن

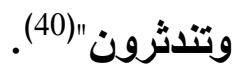

وفي موضع آخر من الدسرحية ذاتها يقول العجوز : "العجوز: .......، يا أبنائي، أنتم زهور غصن واحد ولآلئ عقد واحد، وصلاح أمركم في الاححاد معاً ومساعدة بعضكم

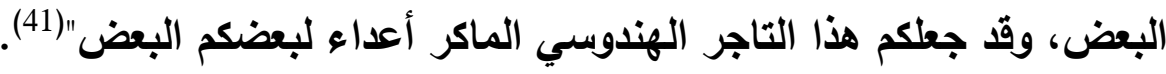

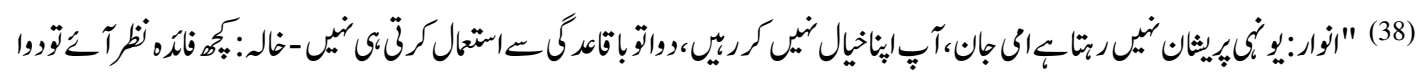

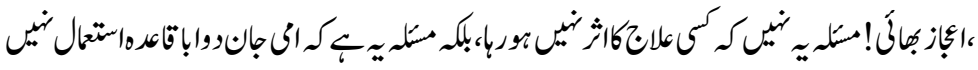
أوار: -

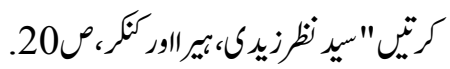

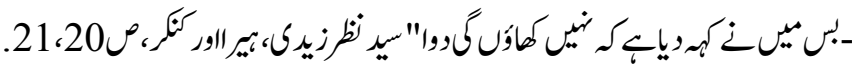

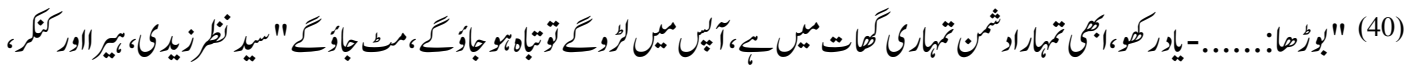
$.300^{0}$

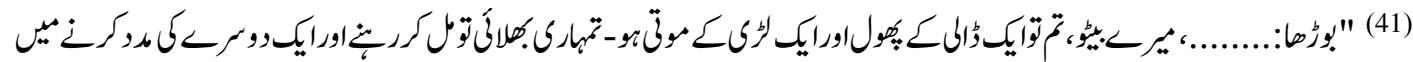

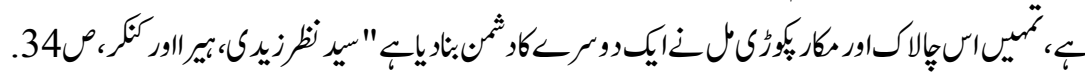


وهكذا عرض الأديب هذه القيمة المصاحبة بأسلوب مباشر عن طريق الإيجاب والنفي كي ييرزها ويميزها في أذهان الأطفال، فيعتادوا عليها نمطاً وسلوكاً في حياتهم.

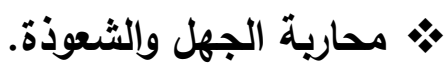

قدم الأديب هذه القيمة كقيمة أساسية من خلال أحداث مسرحية "روطانهلان: العلاج

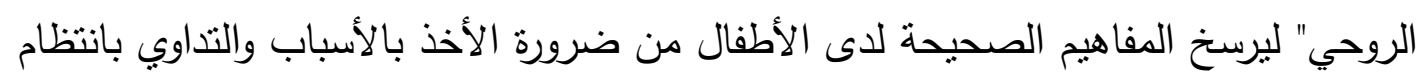

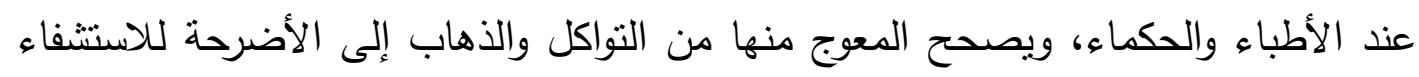

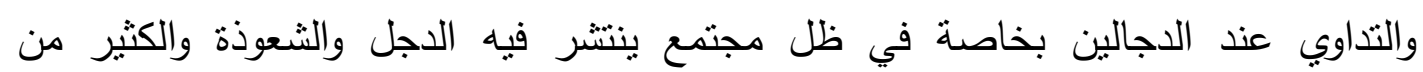

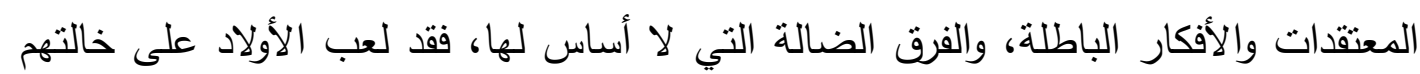

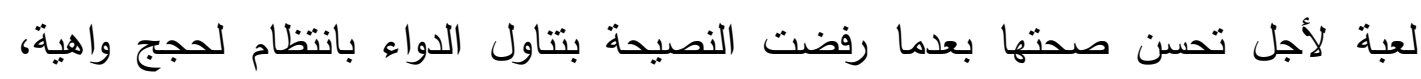

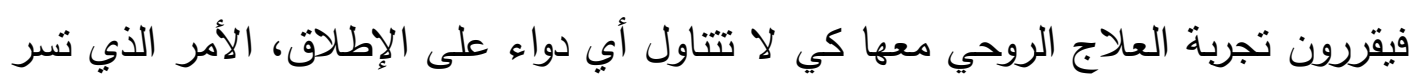

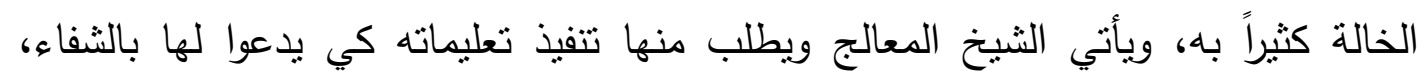

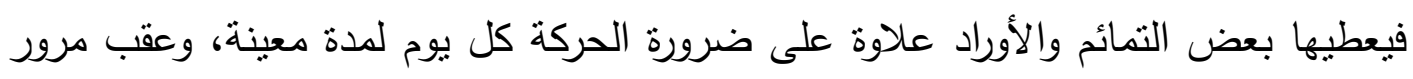

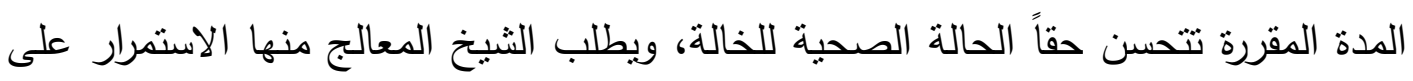
هذا الصنيع كي يزول الألم من قدميها، والذى هو بسبب عدم تحريكهما واستمرار بقائهما

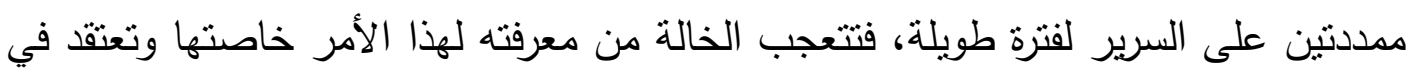

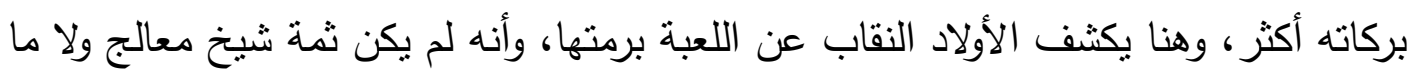

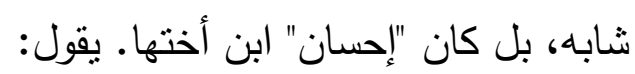

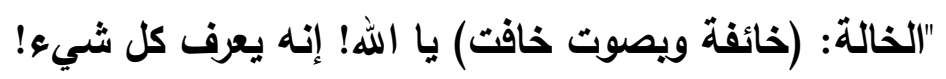

إعجاز: (ضاحكاً) ولم لا يعرف، إنه فضيلة شيخ حقيقي، فلتتفضلي بمقابلتها

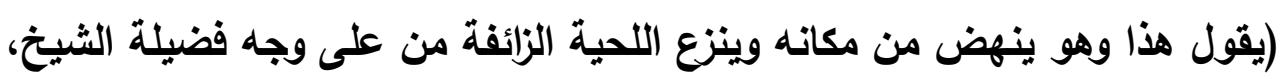
تنده الخالة وتتراجع للخلف، لكنها تطمئن عقب التعرف على إحسان)"(42).

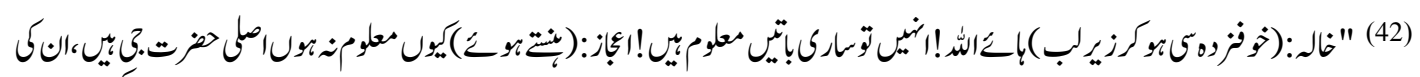

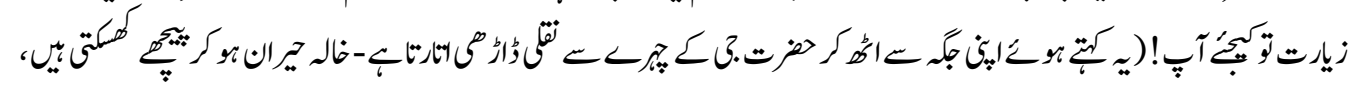

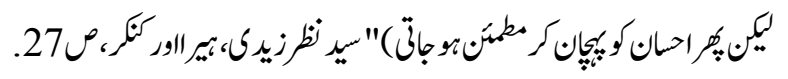




\section{التكاتف والاتحاد.}

دعا الأديب من خلال أحداث مسرحية "روست نمارثم: عدو كصديق" إلى قيمة التكاتق والاتحاد، حيث أبرز أن الاتحاد قوة والفرقة ضعف، وأكد على هذا المعنى كقيمة أساسية، بخاصة إذا أخذنا بعين الاعتبار ظروف قيام الدولة الباكستانية، وانفصال شطرها

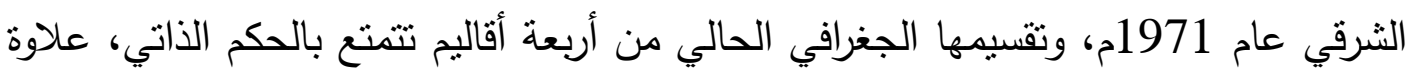

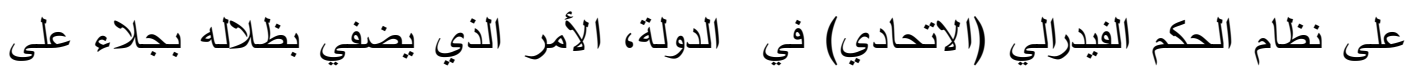
ضرورة وحدة أبنائها واصطفافهم جميعا في مواجهة عدوهم ومكائده، وعدم انسياقه وراء الدعوات والعصبيات المحلية والإقليمية، وهذا بالضبط عين ما أراده الأديب من خلال أحداث

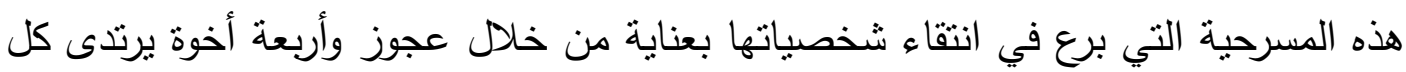
منهم حلة تشير إلى أحد أقاليم باكستان الأربعة، وقد نجحوا بفضل اتحادهم في امتلاكى أراضي قريتهم وبيوتها، لكنهم يريدون تقسيم هذه الممنلكات فيما بينهم. يقول على لسان العجوز: "العجوز: (محتداً) أجزاء! كيف؟ فهذه الأرض وهذه البيوت ملك لكم جميعاً، وستعملون جميعاً معاً، فهل نسيتم أنه بفضل اتحادكم قد تحقق هذا النجاح، وأن اتحادكم ذاته سيضمن النجاح في المستقبل"(43). لكنهم يتجادلون حتى يصل الأمر إلى تشاجرهم بالأبدي مع بعضهم البعض، ويتدخل

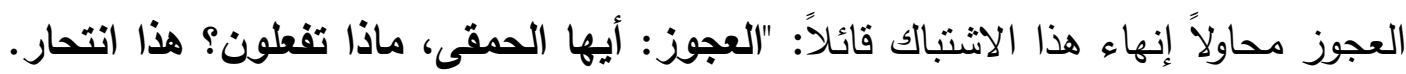
تذكروا، إن عدوكم الآن بالمرصاد لكم، فإذا تثاجرتم مع بعضكم فستدمرون وتندثرون" (44). في تلك الأثناء يدخل عليهم التاجر الهندوسي مبتسماً ومظهراً صداقته ومحبته، لكن العجوز كان واثقاً أن التاجر الهندوسي هو الذي يقف خلف هذه الأنانية التي سمدت أذهان أبنائه نظراً لإرادته الخفية الاستيلاء على هذه الأرض وتلك البيوت التي امتلكوها، وبالفعل يشرع في استقطاب كل واحد منهم على حدة مسمماً أفكاره تجاه العجوز وإخوانه الآخرين حتى

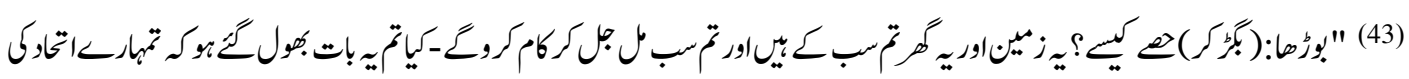

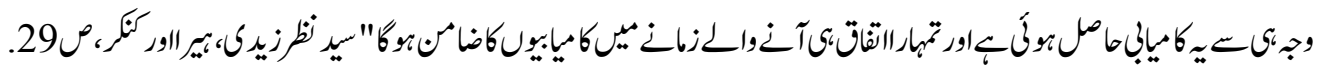

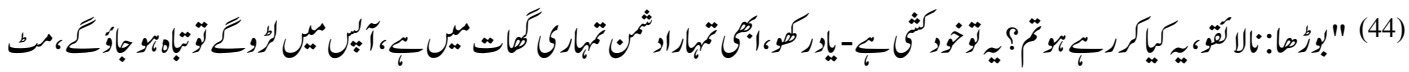

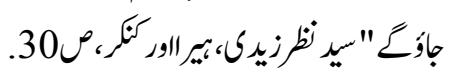


يتقاتلوا ويصييوا بعضهم البعض بإصابات بالغة. يقول: "يدخل الثباب الأربعة يعرجون

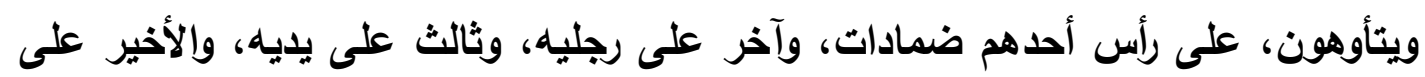

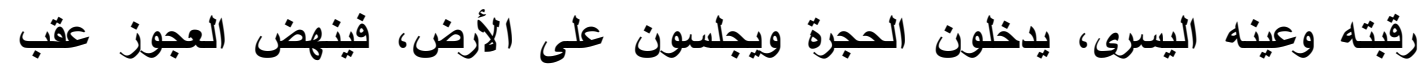

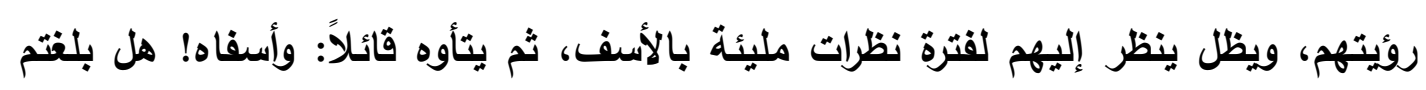

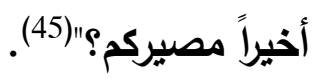
ثم يبين لهم العجوز عدوهم الحقيقي الذي أغدق عليهم السلاح والأموال والأفكار

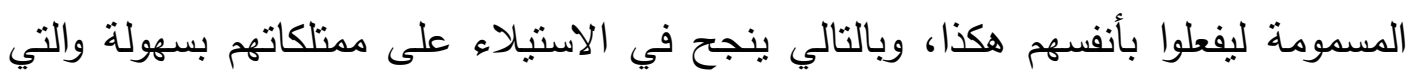

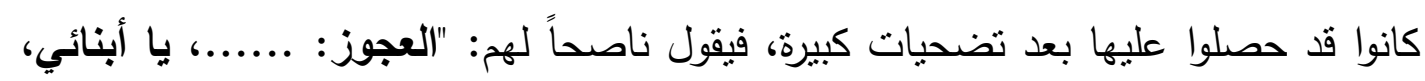

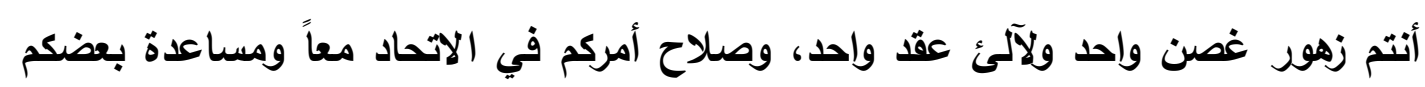

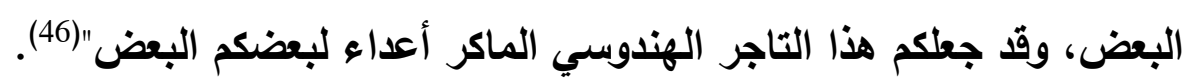

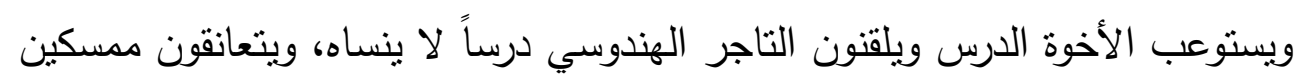

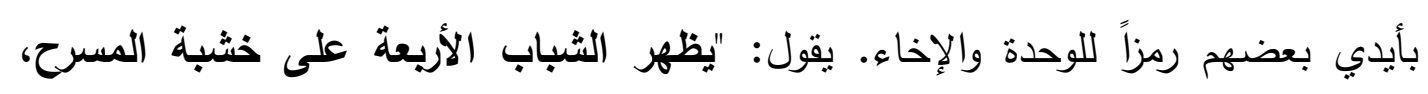

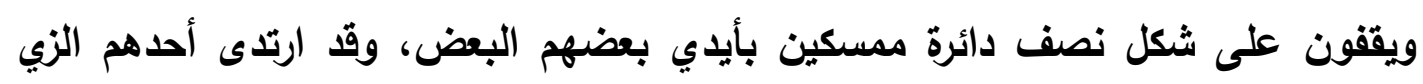

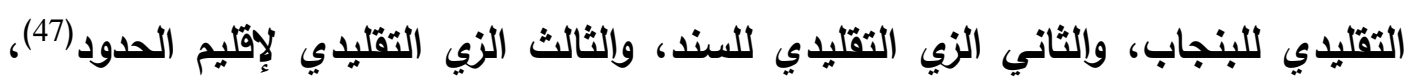

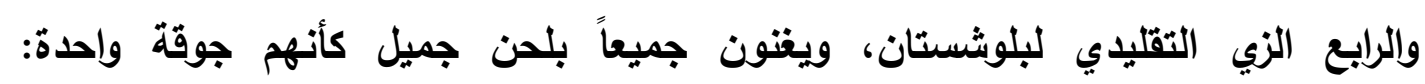
(48)"....

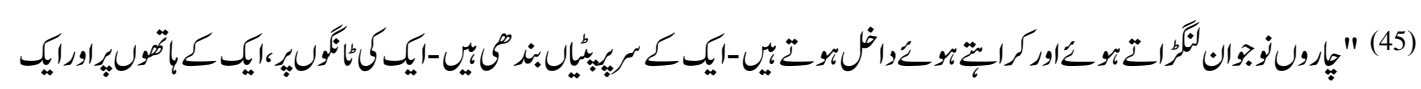

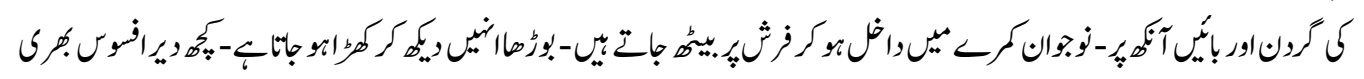

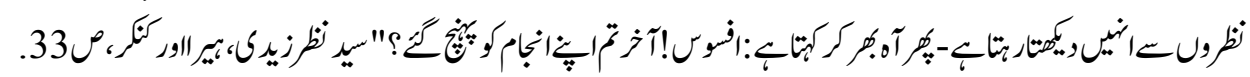

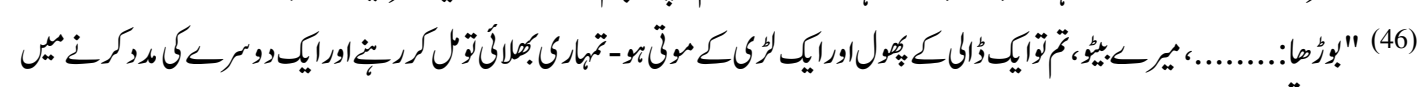

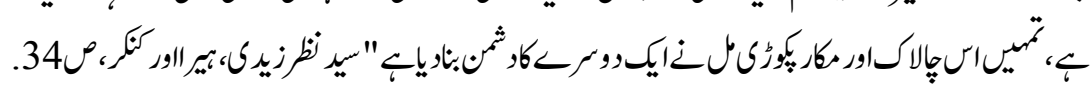

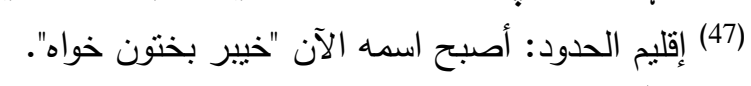

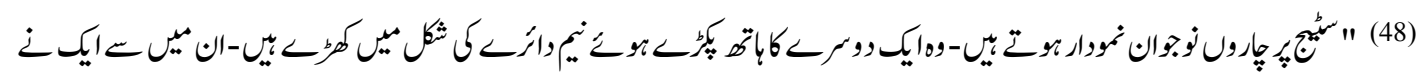

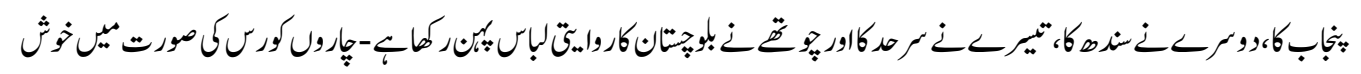

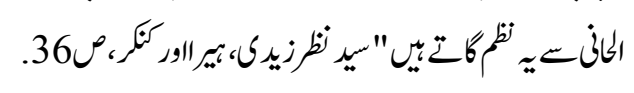




\section{ثانيًا: القيم الاينية}

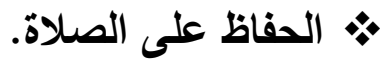

الصلاة عماد الدين، والركن الثاني من أركان الإسلام، وقد أمر الله المسلمين بالحفاظ

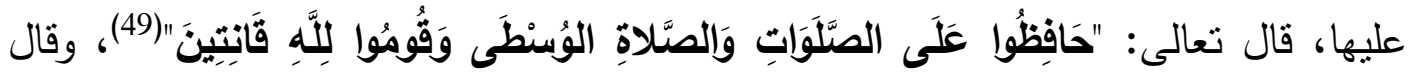
رسول الهه استخفافاً بحقهن كان له عند الله عهد أن ياخله الجنة، ومن لم يأت بهن فليس لله عند الله

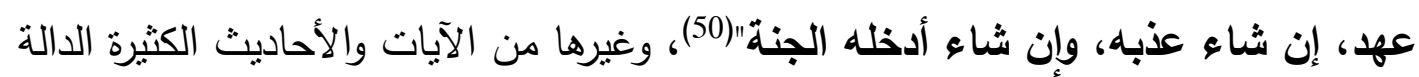
على عظم وأهمية هذه القيمة.

وقد حرص الأديب على تضمين هذه القيمة في مجموعته المسرحية نظراً لأهميتها وعلو شأنها، ففى مسرحية "روحاظعلان: العلاج الروحي" يقول الثيخ المعالج سائلاً الخالة:

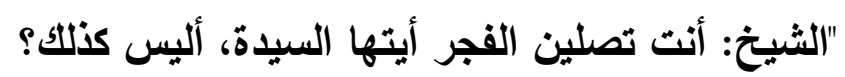
الخالة: صلاة الفجر فقط! أنا بفضل الله أصلي الصلوات الخمس. الشيخ: الحمد لله، الحمد لله، مبارك لك اهتمامك بالصلاة وإلا فقد نسي الناس الله

\section{هذه الأيام"(51).}

وقد أوردها الأديب كقيمة مصاحبة بأسلوب مباشر ضمن طريقة العلاج التي وصفها الثيخ المعالج للخالة لإبراز أهميتها والتأكيد عليها وغرسها في نفوس الأطفال. طاعة الوالدين.

هي القيمة الأساسية لمسرحية "الكَرعا: دعاء الأم" والتي حرص الأديب على إبرازها

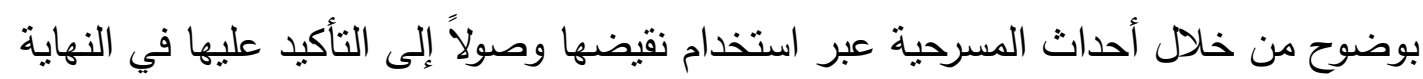

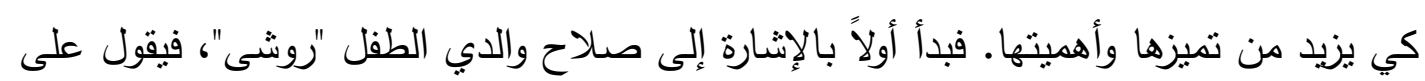

$$
\text { 238 سورة البقرة، الآية }
$$

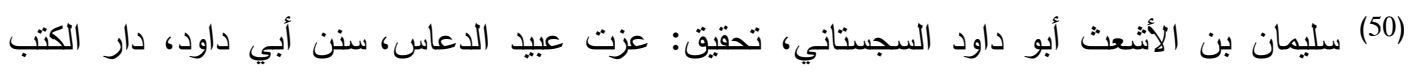

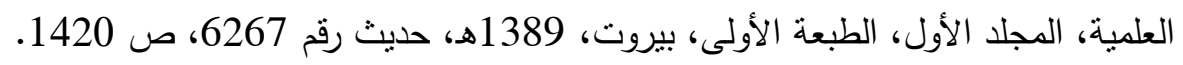

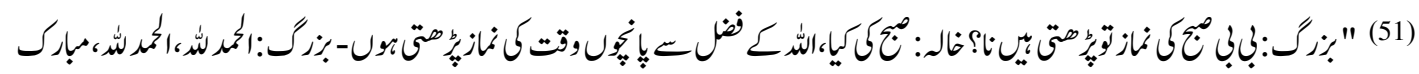

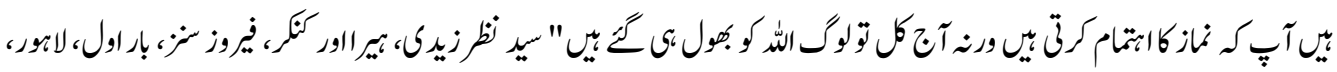


لسان ملك الحسنات: "الملك الثاني: ....... وسيصبح أيضاً ضابطاً كبيراً مثل والده المحترم، وأنا أقول هذا لأن واللايه كليهما صالحان جداً"(52). ثم انتقل إلى الطفل "روشى" ذاته الذي يتخذ الثيطان صديقاً يتبع خطواته، ويعصي والديه، فيقول على لسان الثيطان: "الثيطان: لا شك أن والديه صالحان لكنهما ليسا أكثر دهاء مني (يضحك)، وهذا الولا أصبح صديقي الصدوق، يطيع أمري ويعصي أمر والايـه"(53).

وبعد ذلك يشب الولا ويصدق عليه كلام الثيطان حيث يصبح لصاً خطيراً، الأمر الذي يحزن والديه كثيراً، فنترع والدته في السجود باكية منضرعة إلى الله عز وجل أن يصلح حال ابنها، ويحفظه من عاقبة السوء، وبالفعل يستجيب الله دعاءها بفضله ورحمته، ويتحول الولد من مجرم خطير إلى بطل قومي يساعد الثرطة في القبض على رفاقه المجرمين، ويعلن توبته ويدعو الله أن يبعده عن كل سوء، فيقول له الضابط في النهاية: "ضابط الثرطة: يا بني! لا بد أيضاً مع التوية ألا تغضب والديك أبداً. روشي: (يرفع يايه بالدعاء) اللهم وفقتي لخدمة والدي وإسعادهما"(54). وهكذا أبرز الأديب هذه القيمة الغالية من خلال نقيضها باتباع الولد للشيطان

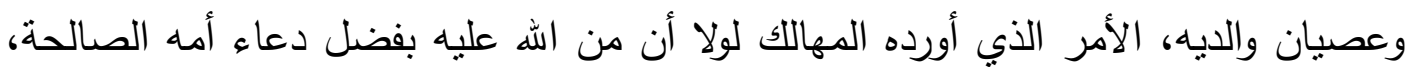

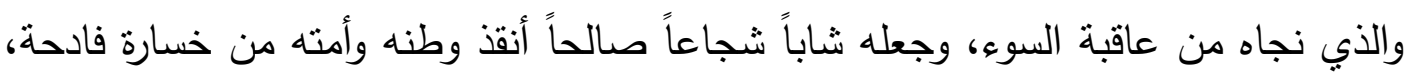
فتحول بفضل دعاء أمه من مجرم خطير إلى بطل قومي يعلن نوبته وترك طريق الثيطان، ويعزم على طاعة والديه وإسعادهما.

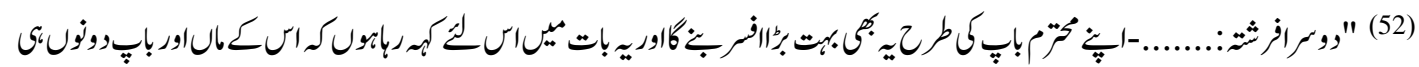

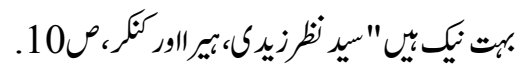

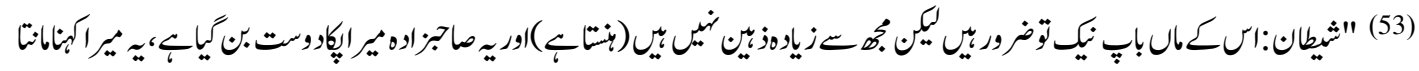

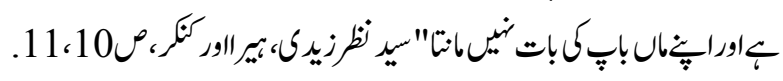

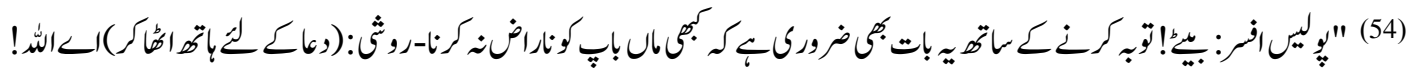

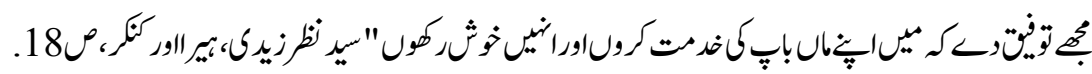




\section{هن الظن بالله.}

حرص الأديب على تقديم هذه القيمة الدينية الرفيعة للأطفال في أكثر من موضع كي يغرسها في نفوسهم، ويملأ بها قلوبهر، ويستصحبونها طوال حياتهم في جميع شئونهم.

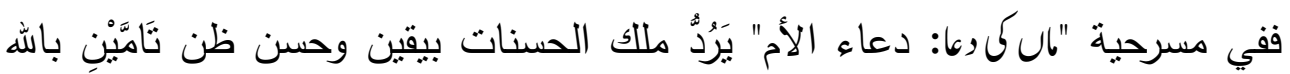
على الثيطان الذي يتمنى الإعدام لجميع البشر على وجه الأرض قاطبة نظراً لما آل إليه بسبب أبيهم آدم عليه السلام. يقول: "الملك الثاني: لكن أيها الرجيم! اعلم جيداً أن أمنيتك الإدئ لن تتحقق أبداً بأن ينغدع بك جميع البشر في العالم ويتم عقابهم كمجرمين، إن شاء الله ستظل مصابيح الخير مضيئة، وسيستحق عدد كبير من البشر رحمة الله"(55). وفي موضع آخر من المسرحية ذاتها يرد ملك الحسنات بيقين تام على ملك السيئات الذي يخبره بأن الألم الحقيقي للوالدين سيحدث عندما يسمعان خبر إعدام ابنهما. يقول: "الملك الثاني: لكن قد لا يحدث هذا، فأتت ترى أمه تظل تبكي وتدعو ربها، وإني على يقين بأن

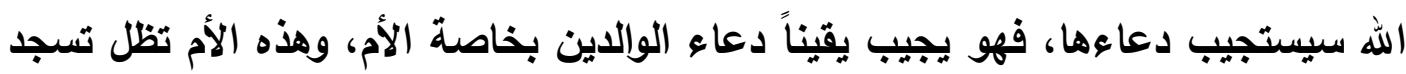
وتبكي وتدعو لابنها، وسيقبل دعاعها يقيناً"(56). وفي موضع ثالث من المسرحية ذاتها يقول ملك الحسنات في ذات السياق: "الملك

الثاني: ......، لكني على يقين تام بأن الله الرحيم سيستجيب يقيناً دعاء أمهـ"(57).

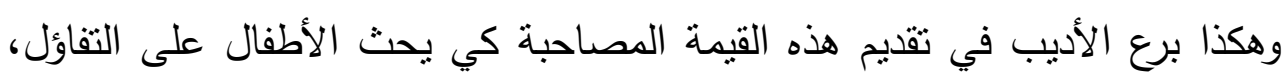
وأن بعد العسر يسرا، وأن مع الدعاء حسن ظن باله أنه سيستجيب الدعاء، فبيده الخير وهو

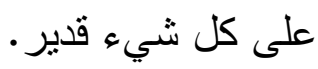

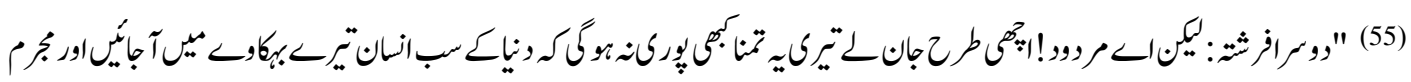

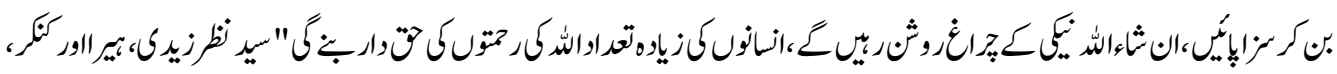

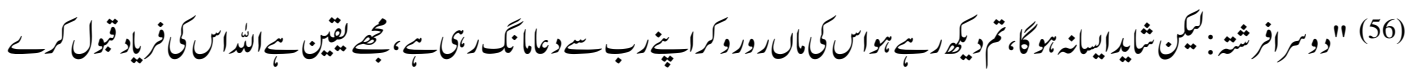

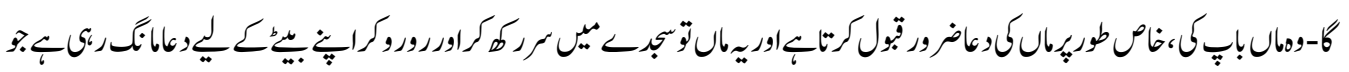

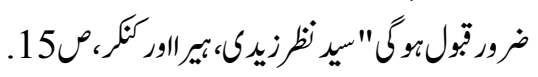

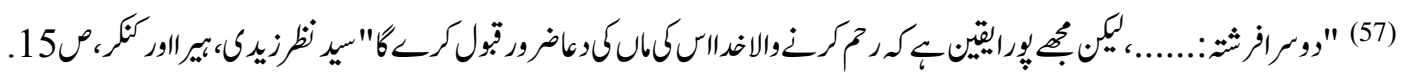




\section{+ (التضرع والدعاء.}

يوجه الأديب الأطفال من خلا هذه القيمة إلى حسن اللجوء والتضرع إلى الله هيَّلَ في السراء والضراء، وتَذَكُّهِ سبحانه وتعالي وقت الثدة وعند حلول البلاء بالدعاء والإنابة إليه كي يتعلموا أن الله مطلع علينا، ويسمع دعاء المضطر ويجيبه، ويكثف الضر والسوء بفضله

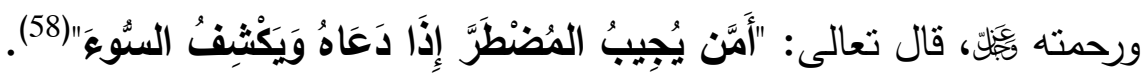
ففي مسرحية "الكروطا: دعاء الأم" تضطرب أم "روشى" وتترع في البكاء بعد سماعها خبر انخراط ابنها "روشى" مع مجموعة من اللصوص، وأنه سرعان ما سيتم القبض عليهم، فتأخذ في الدعاء وهي تبكي قائلة: "الأم: يا ربي! يا إلهي! نجنا من الصدمة، واحفظ ابني

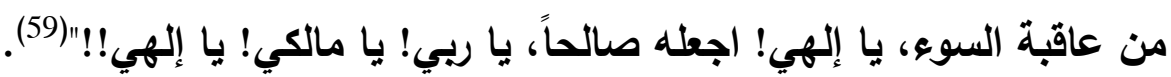

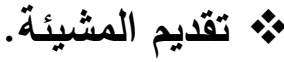

من القيم الدينية التي حرص الأديب على تقديمها للطفل في أكثر من موضع قيمة

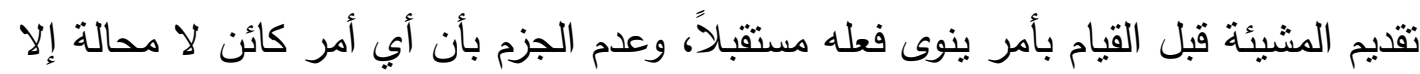

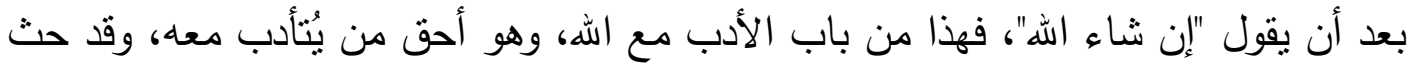

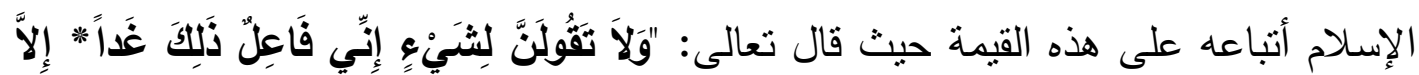
أَنْ يَشَنَاءَ اللَّهُهُ" (60).

فقى مسرحية "روانظ علاج: العلاج الروحي" يقول الأديب على لسان كل من "انوار"

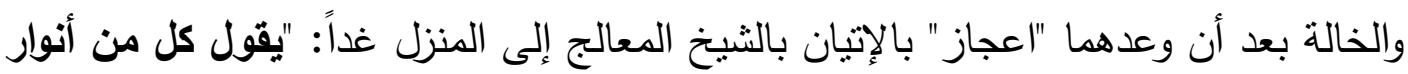

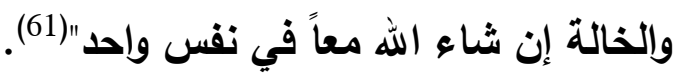
وفي موضع آخر من المسرحية ذاتها يقول "انوار" مخاطباً الثيخ المعالج: "أنوار :.......، عندما تدعو فضيلتك فإن شاء الله ستثفى أمي العزيزة"(62).

$$
\text { . (58) سورة النمل، الآية } 62 \text { (5) }
$$

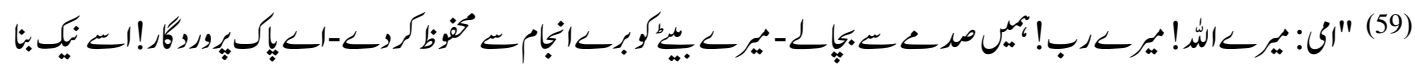

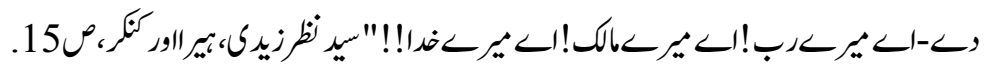

24) 20) سورة الكهف، الآينان 23 (60)

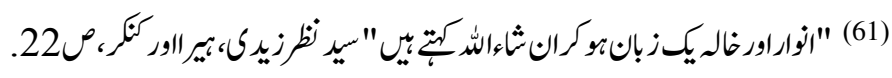

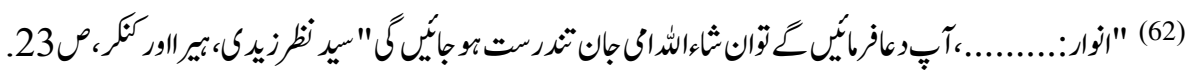


وفي موضع ثالث من المسرحية ذاتها يقول الثيخ المعالج مخاطباً الخالة: "فضيلة

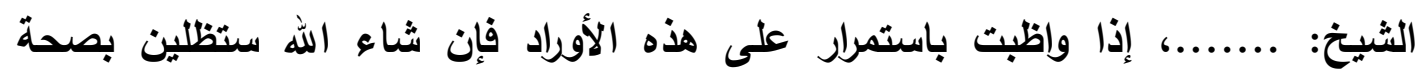

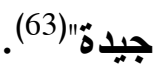

وهكذا أورد الأديب هذه القيمة في أكثر من موضع في المسرحية نأكيداً على أهميتها، وقد جاءت كقيمة مصاحبة بأسلوب مباشر .

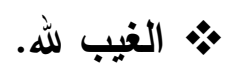

إحدى القيم الدينية التي حرص الأديب على بثها للطفل كي تكون لديه خلفية دينية

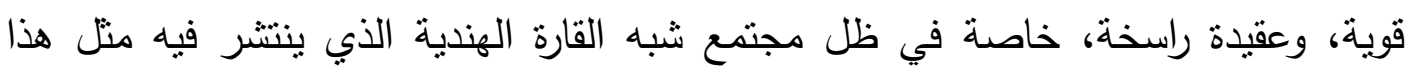

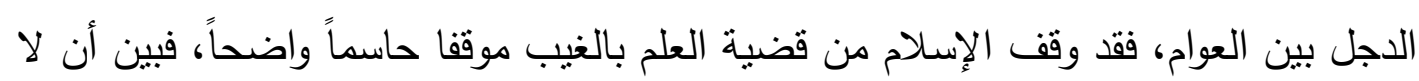

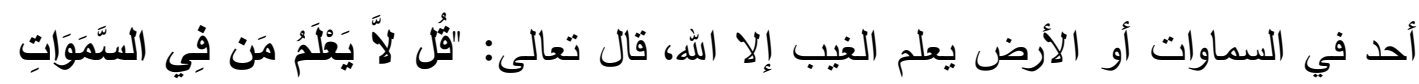

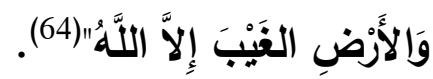

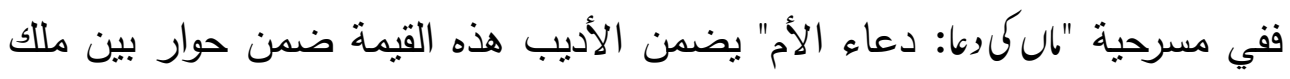

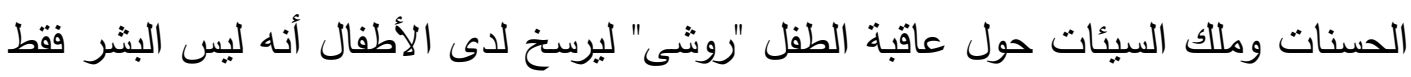
بل حتى الملائكة أنفسهم لا يعلمون الغيب. يقول: "الملك الأول: ستكون عاقبته وخيمة، وسيقضي أغلب عمره في السجن، وسيتم إعدامه في النهاية. الكلتك الثاني: استغفر الله يا أخي! ما هذا الذي تقول؟ فالغيب يطلمه الله وحده، فكيف يمكنك القول إذن بأن عاقبة هذا الطقل ستكون وخيمة؟ الها

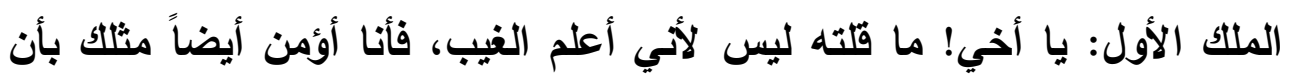

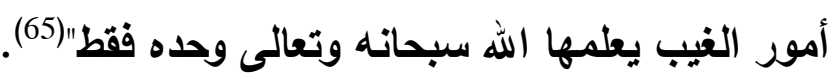

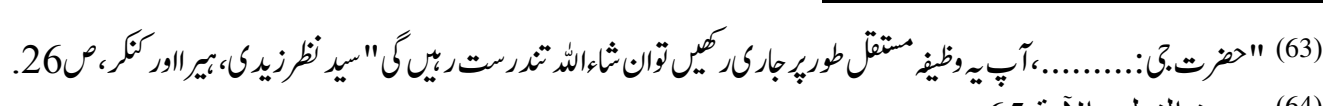

(64) سورة النمل، الآية 65.

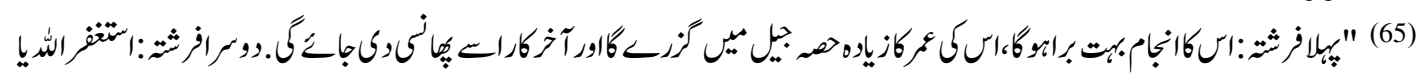

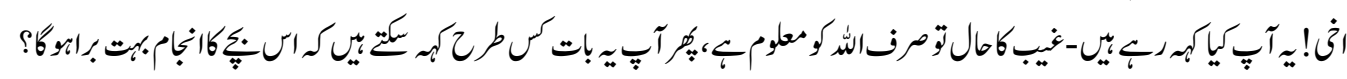

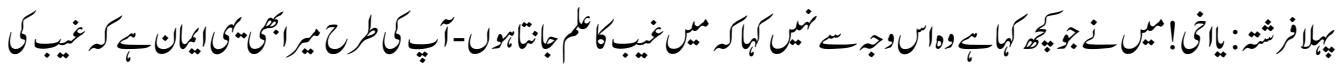

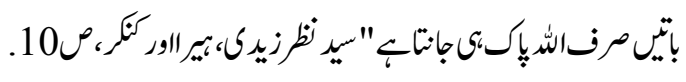


وهكذا برع الأديب في غرس هذه القيمة المصاحبة في نفوس الأطفال منذ البداية حتى يدركوا جيداً أن علم الغيب من اختصاص الله وحده فقط، وأنه لا يمكن حتى للملائكة أنفسهر علم الغيب، بل إنهم يقرون بأنه وحده سبحانه عالم الغيب والثهادة، فكيف الحال إذن الن النان بمن هم دونهم من الدجالين والششعوذين.

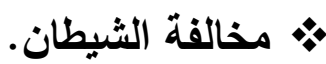

حرص الأديب على تضمين هذه القيمة الدينية المهمة في مجموعته المسرحية كي يبين للأطفال عداوة الثيطان القديمة والظاهرة والبينة للإنسان، فقد نوعد الثنيطان بنى آدم قاطبة، وأعلن عن خبث عداوته لهم بتزيين الدعاصي، والإغراء بالمحرمات والخبائث، والأمر الفران بالسوء والفشثاء؛ لذا بين لنا الله عز وجل عداوته، وحذرنا من اتباع خطواته، فقال تعالى:

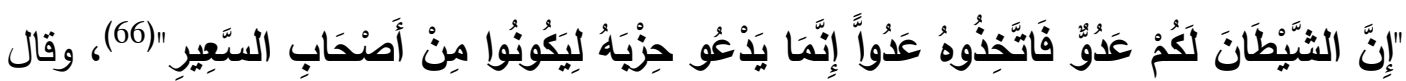

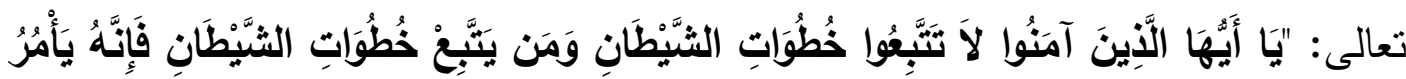

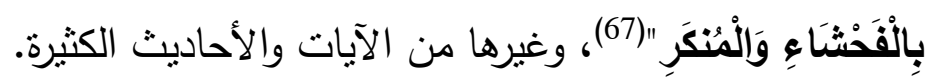

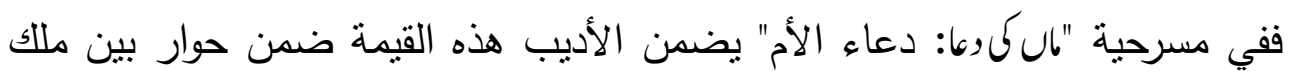
الحسنات والثنيطان لتوضيح عداوته الصريحة للإنسان. يقول: "الملك الثاني: والآن ذلك الملعون الذي غضب الله عليه كثيراً، وسوف يغفر لكبار العصاة، لكنه لن يغفر للك. الثبطان: دعك من أمر لعنتي، فكر في هذا الولا الجميل الذي سأجطله لصاً سيتم

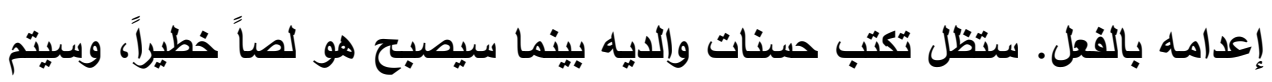
القبض عليه مراراً وتكراراً والزج به في السجن وإعدامه في النهاية"(68).

$$
\text { (67) سورة النور، الآية } 21 \text { الآية } 6 .
$$

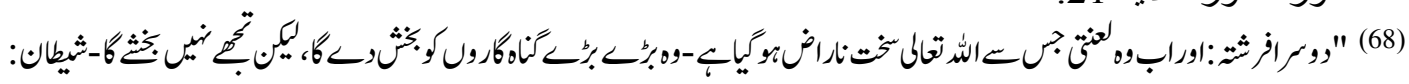

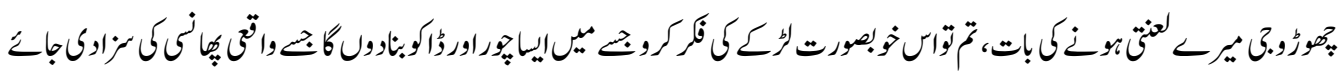

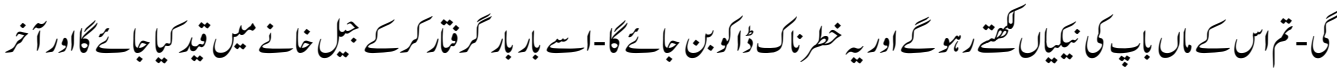

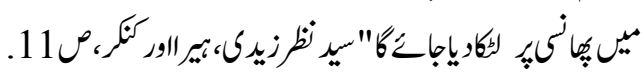


وفي موضع آخر من المسرحية ذاتها يطلب ملك الحسنات من الثنيطان أن يرحم هذا

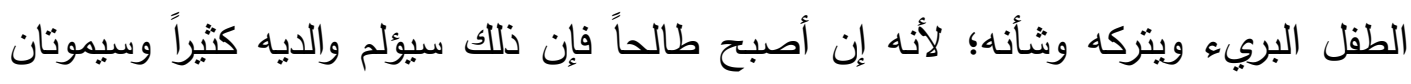

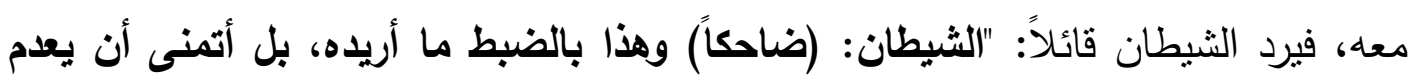
جميع البشر على وجه هذه الأرض، فقد أضحى هذا حالي بسبب أبيهه جميعاً آدم" (69).

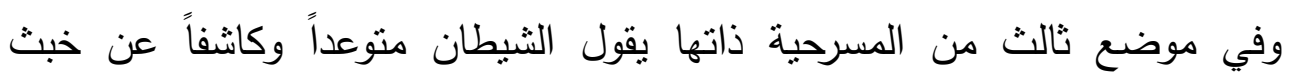

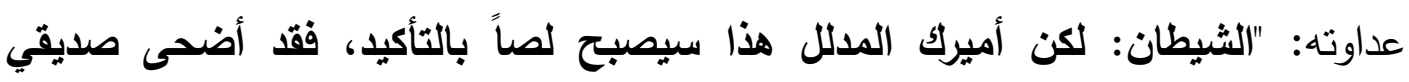

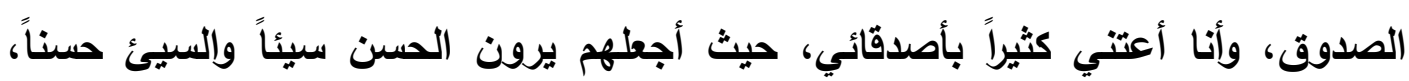
وهكذا يصيرون مجرمين حقاً، فيكرهم الله وكذلك الخلق" (70).

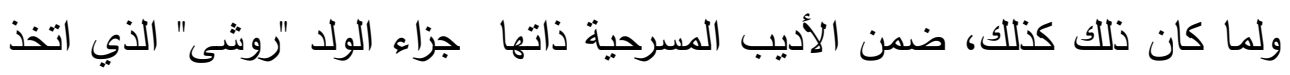

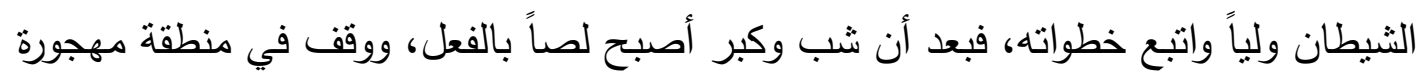

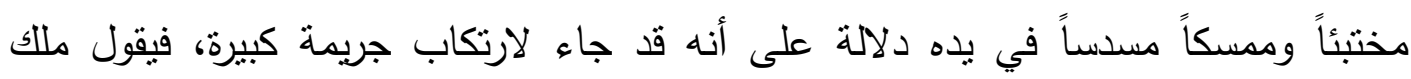

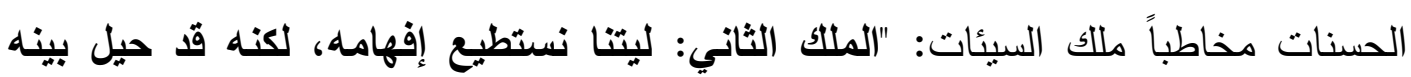

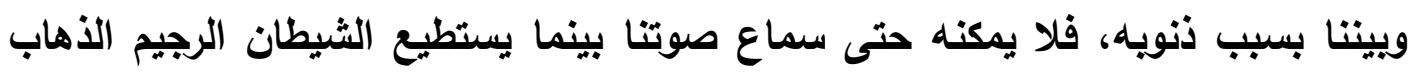

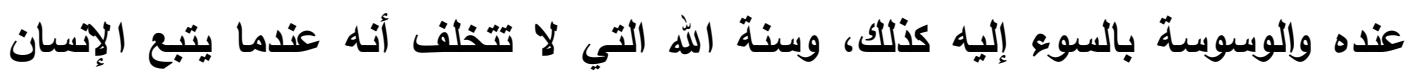

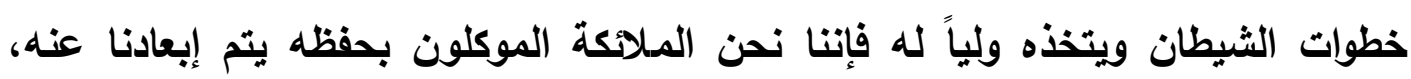

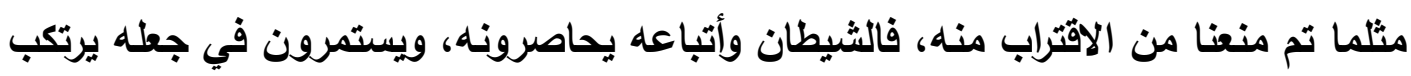
مثل هذه الذنوب التي تجطله يستحق أقصى عقوية مثلما يفعل هذا التعيس الآن" (71).

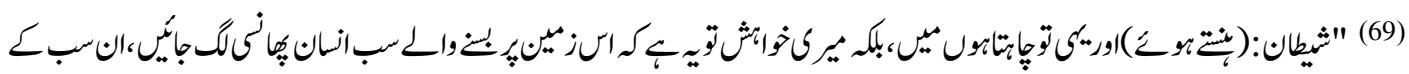

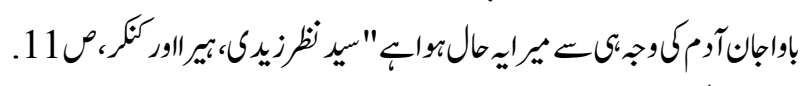

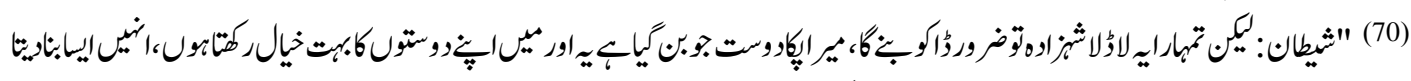

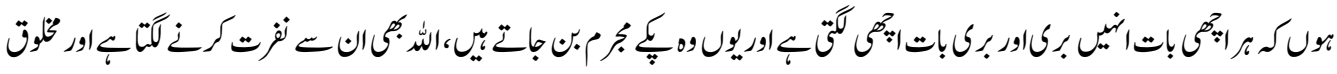

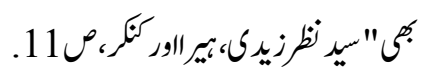

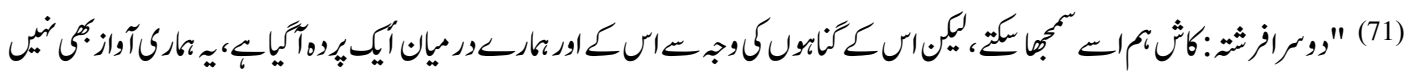

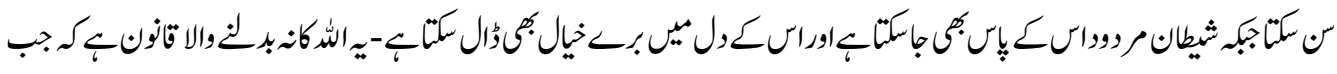

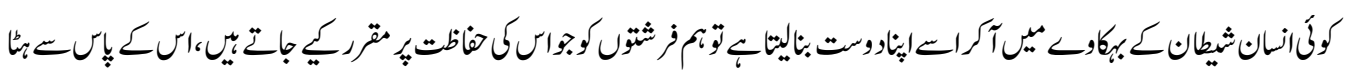


وهكذا نجح الأديب في تصوير قيمة ضرورة مخالفة الثيطان وبيان عداوته الثديدة

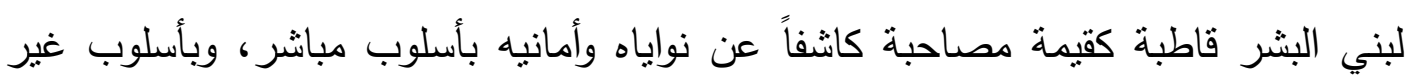
مباشر عبر بيان جزاء اتباعه، كي يحذر الأطفال من وساوسه فلا ينساقون وراءها، ويتخذوه عدواً يتحصنون منه بطاعة الله وبر الوالدين. ثالثًا: القيم الأخلاقية

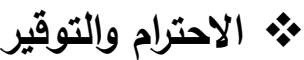

حث الأديب الأطفال على وجوب احترام الآخر لما فيه من زيادة الحب والوئام بين أفراد المجتمع، الأمر الذي يساعد في تقدمه ورقيه، حيث يدفعه هذا الاحترام المتبادل بين أفراده إلى التعاون والاتحاد، ويبعده عن كل ما فيه فردية أو شقاق، وهو ما حثنا عليه ديننا

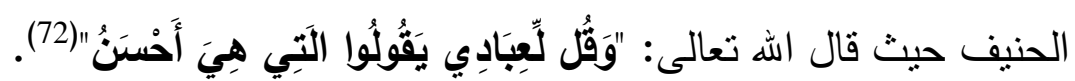
وقد قدم الأديب هذه القيمة من خلا احترام الشخصيات لبعضهم البعض في في ثنايا حوارهم، ومناداتهم لبعضهم بالألقاب، وكذا من خلال محاولة استرضائهم والاعتذار الفوري

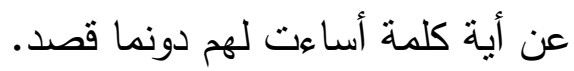
ففى مسرحية "بير|اوركنر: الماس والحصى" يقول "عثمان" مخاطباً "عامر" ابن خالته:

\section{"عثمان: دعني أعمل أيها الأخ المحترم العزيز"(73).}

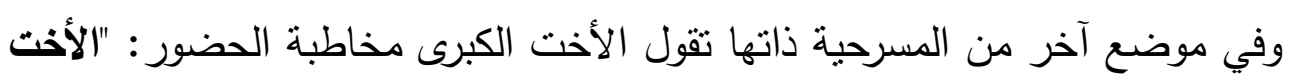
الكبرى: الوالد العزيز، والأم الحبيبة، والخالة الكريمة، والأساتذة الكرام، والسادة الضيوف دانها المحترمون"(74).

مما سبق يتضح مدى حرص الأديب على استخدام كلمات دالة على الاحترام والتوقير

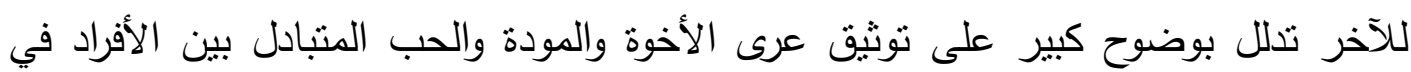
حديثهم مع بعضهم البعض مثل: أخي، السيد، المحترم، العزبز، الحبيب، وغيرها.

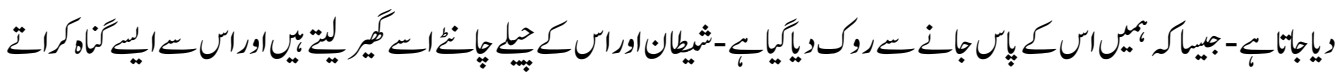

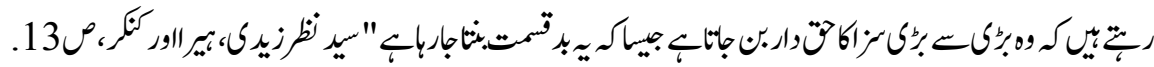

(72) سورة الإسراء، الآية 53.

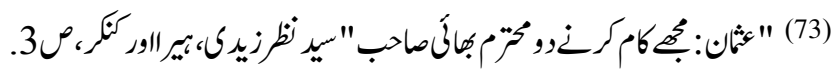

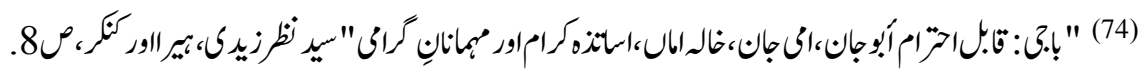


كما نرى اهتمام الأديب بتوضيح نموذج آخر أكثر ذوقًا واحتراماً وهو الوقوف نحية

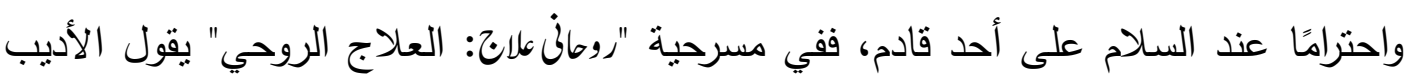

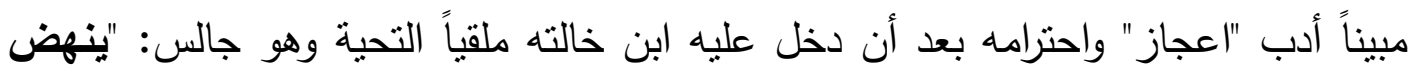
اعجاز من على الكرسي ويصافح قائلاً وعليكم السلام" (75). وفي موضع آخر من المسرحية ذاتها يوضح الأديب نموذجاً آخر للاحترام من خلال محاولة كل من "اعجاز" و "انوار" استرضاء الخالة والاعنذار عن الإساءة غير الدقصودة:

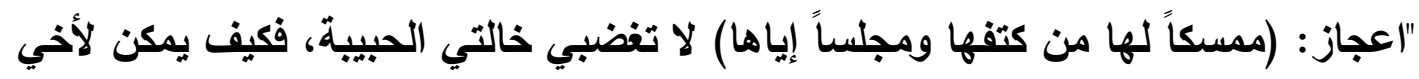

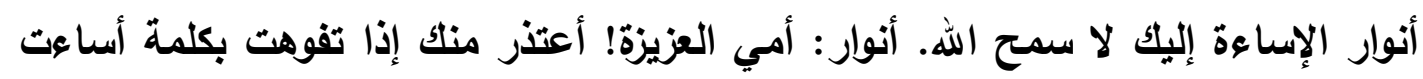
إليك حال قلقي" (76). وفي موضع آخر من المسرحية ذاتها يوضح الأديب نموذجاً آخر للاحترام والتأدب

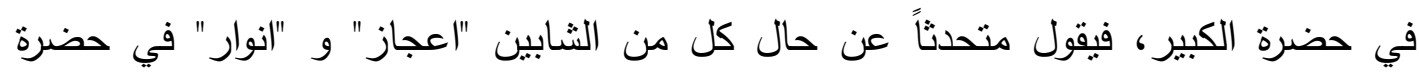

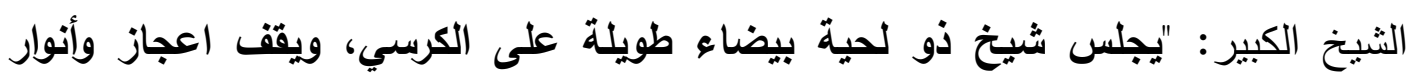

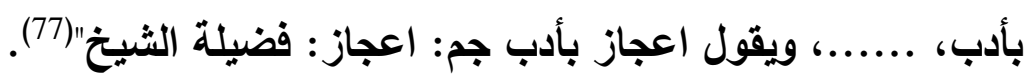

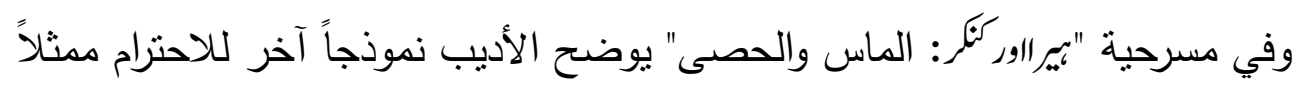

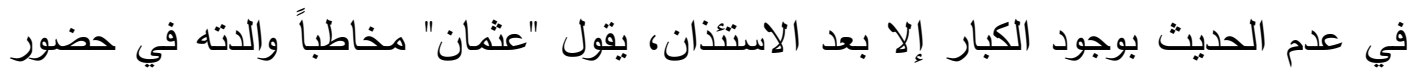

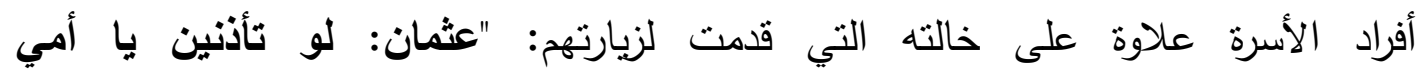
فسأخبرك..........." (78).

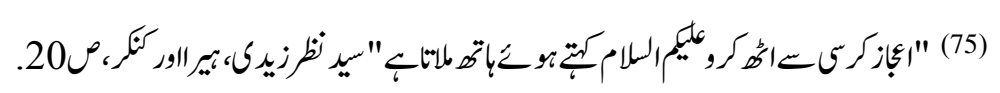

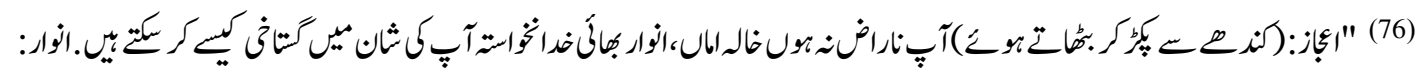

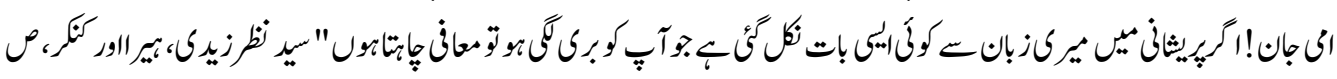

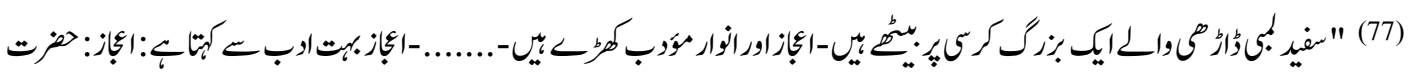

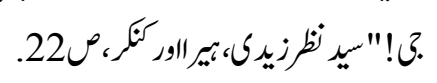

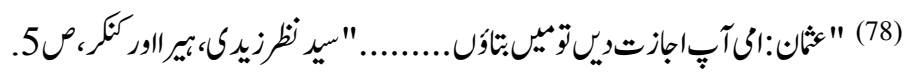


وفي موضع آخر من المسرحية ذاتها يتحدث "عثمان" في حفل تفوقه عن سر تفوقه

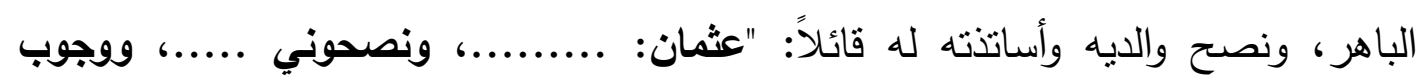
احترام الكبار"(79).

من هنا نرى مدى اهتمام الأديب بنلك القيمة العظيمة والتي استخمها في كل

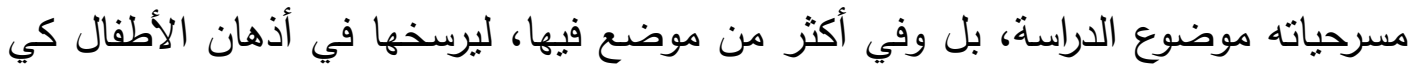

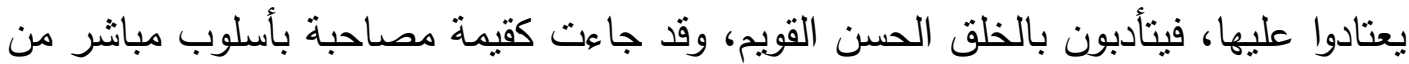
خلال الألفاظ والنماذج التطبيقية الدالة على الاحترام والتوقير . طاعة الكبير

من بين القيم المصاحبة التي اهتم بها الأديب كذللك قيمة السمع والطاعة والإصغاء لرأي الأكبر سناً، حيث دعا إليها تصريحاً كي يمنتل الأطفال لتعليمات الكبار فيطيعونهم فيما

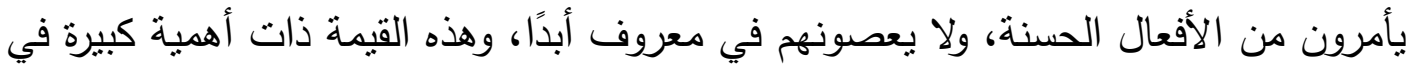
تتشئة الصغار وتربيتهم، وهو ما يجب أن يدعو إليه أدب الأطفال.

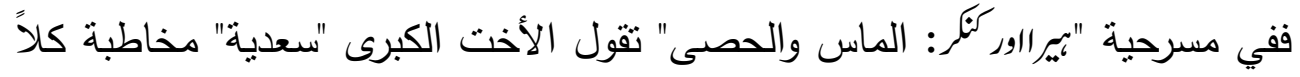

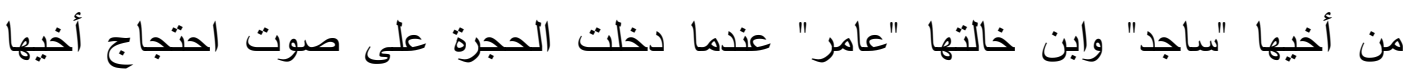
"عثمان": "سعدية: ما هذا، لماذا تزعجان عثمان؟ اتركاه! (يترك كلاهما عثمان)"(80). وفي موضع آخر من المسرحية ذاتها يقول "عثمان" مخاطبًا الحضور في حفل تفوقه:

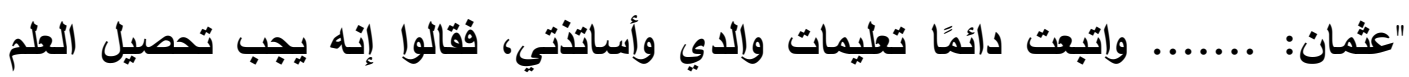
بثغف بالغ، فامتثلت أمرهم هذا بإخلاص واجتهلت كثيراً من أجل تحصيل العلم"(81).

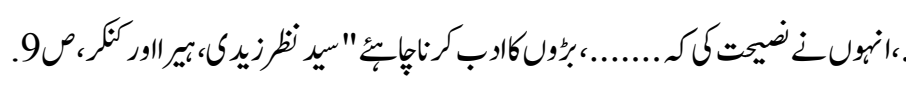

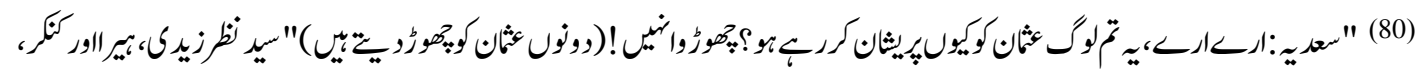
$.30^{0}$

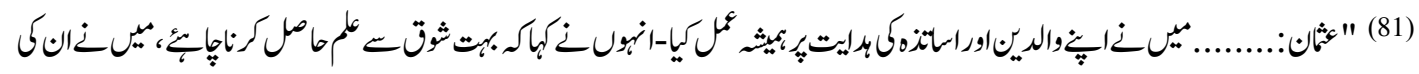

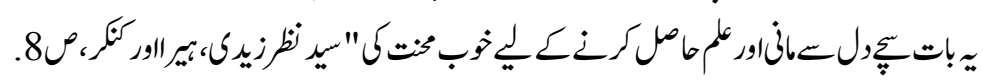




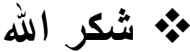

يغرس الأديب في الطفل قيمة مصاحبة أخرى من الأهمية بمكان؛ ألا وهي شكر الله

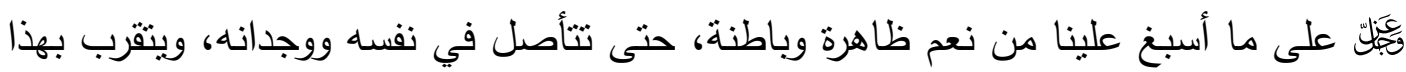

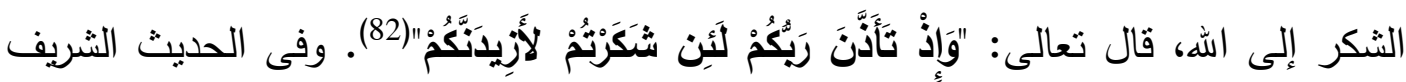

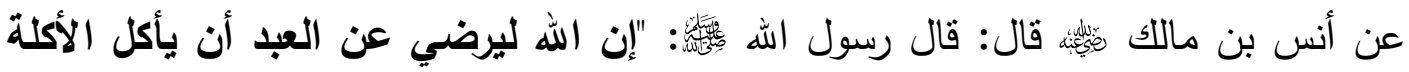

فيحمده عليها، أو يشرب الشربة فيحمده عليها"(83).

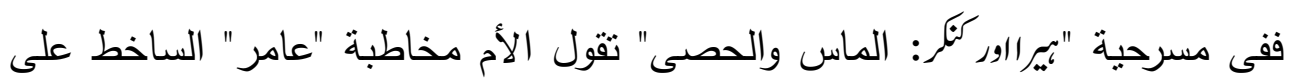
الحياة: "الأم: لم تجحد النعمة يا بني، فالله كَّئ يسخط على الجاحدين"(84). وفي مسرحية "روحانعلان: العلاج الروحي" تقول الخالة بصوت مفعم بالحيوية والإيمان بعد أن تحسنت حالتها: "الخالة: الحمد لله، فحالتي جيدة جداً الآن"(85). العمل الصالح

من القيم المصاحبة التي بثها الأديب قيمة الحث على المسارعة إلى العمل الصالح والانخراط فيه، واجتتاب العمل السيئ والبعد عنه، فلا يحيق المكر السيئ إلا بأهله، قال

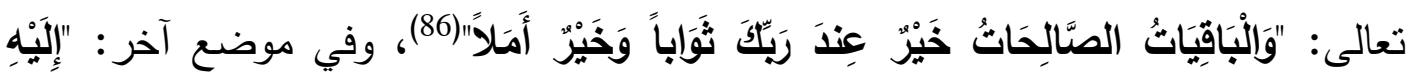

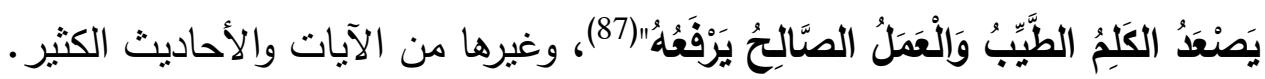
ففي مسرحية "يمراور كنكر: الماس والحصى" يقول الأديب على لسان "عثمان" الذي لئي وقف في حفل تفوقه مخبراً عن سر نجاحه الباهر قائلاً: "عثمان: ......... ونصحوني......، ووجوب تجنب الأمور السيئة، والآخراط في الأعمال الصالحة"(88).

(82) سورة إبراهيم، الآية

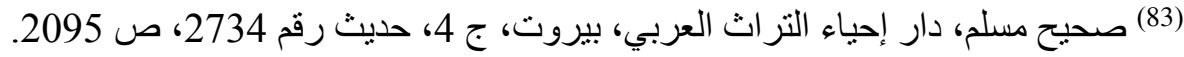

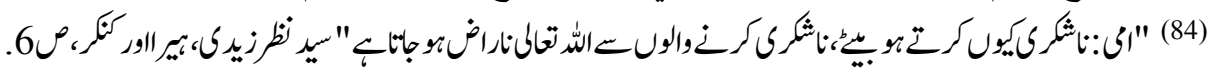

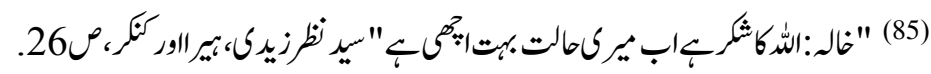
(86) سورة الكهف، الآية 46 (86) (87) سورة فاطر، الآية 10.

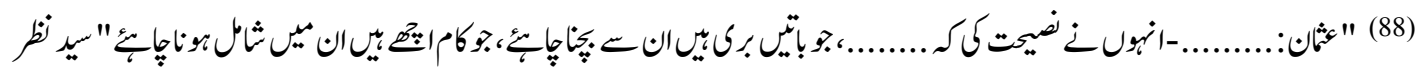

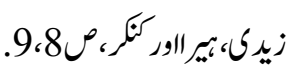


كما أبرز الأديب هذه القيمة عبر الإتيان بنقيضها من خلال أحداث المسرحية ذاتها ، حيث ذكر اتفاق كل من "عامر" و "ساجد" ضد "عثمان" لجعله يرسب في الامتحانات النهائية ولا يحصد أعلى الدرجات كي يتمكن "عامر" من التفوق عليه، والفوز بالجائزة الكبرى التي لتئي

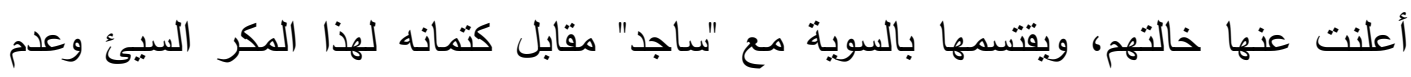

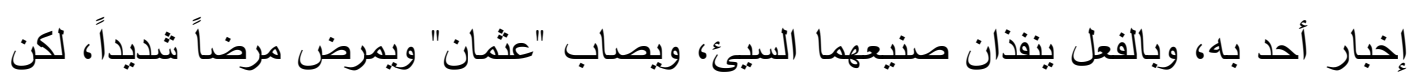

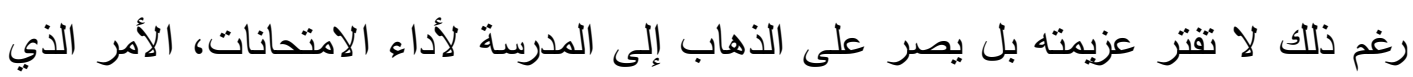

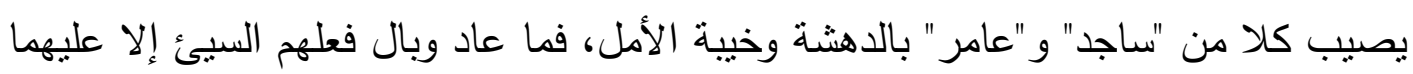

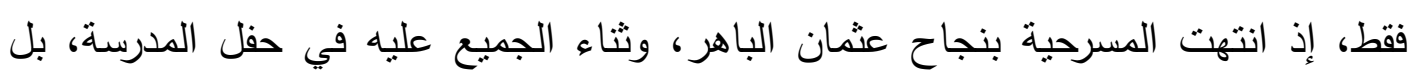

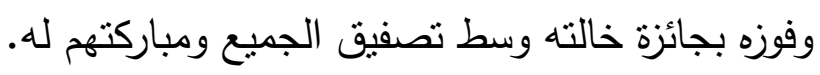

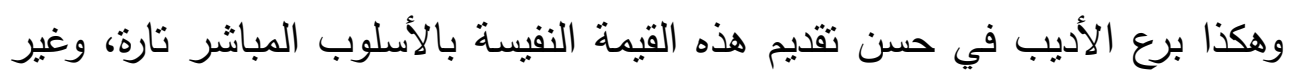
المباشر تارة أخرى، كي يجعل الطفل أكثر فهماً وإدراكاً لها. رابعاً: القيم المعرفية

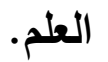

العلم بحر عظيم يحوي ما لا يحصى من الدرر، فهو نور العقل الذي برفع قدر

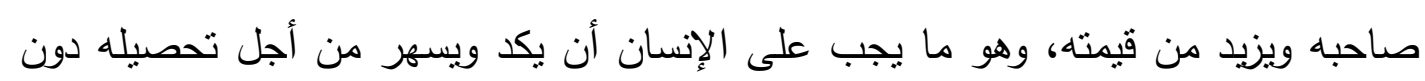
كلل أو ملل.

من هنا حرص الأديب حرصاً بالغاً على توجيه الأطفال وإرشادهم إلى قيمة الجد فيد

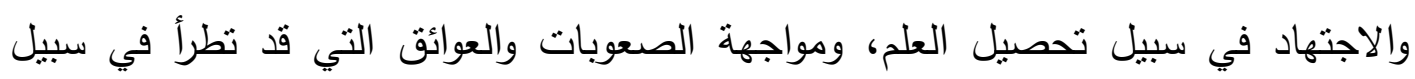

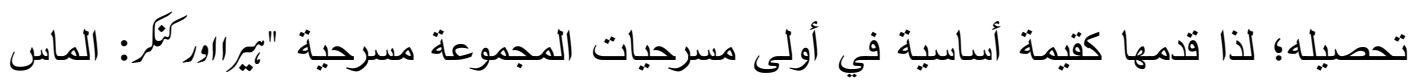

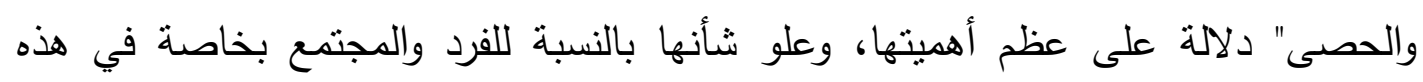

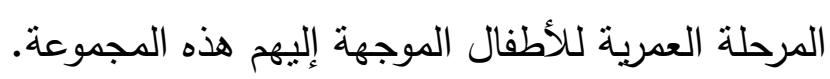

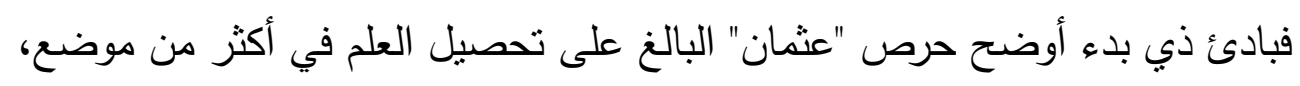

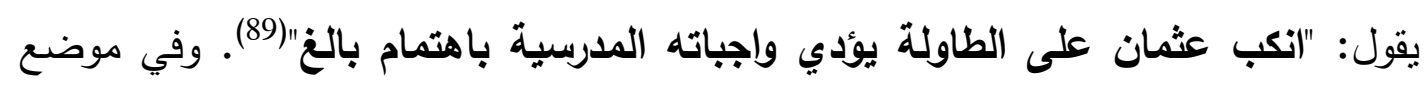

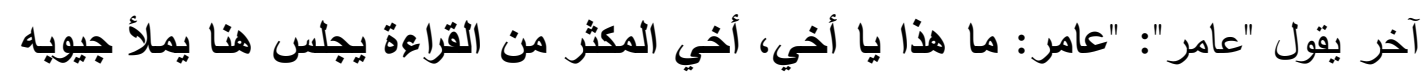

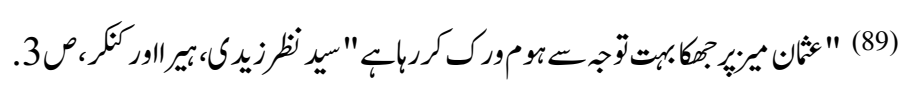


بلرر العلم"(90). وفي موضع آخر بصفه "عامر" قائلاً: "عامر: السيد دودة الكتب!"(91). وفي موضع آخر يقول "ساجد": "ساجد: .......، فمن الواضح أنه يظل منكباً على الكتب طوال الوقت ") (92).

ثم انتقل إلى حرص "عثمان" على أداء واجباته لإرضاء أساتذته، يقول:

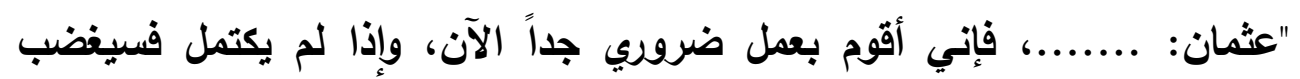

السبد الأستاذ.

ساجد: (ضاحكاً) ومتى يكون سعيداً فقد رأيناه غاضباً على الاوام.

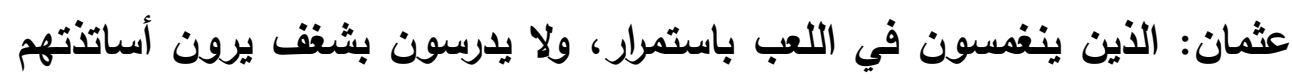
غاضبين" (93).

ثم ذكر حث الخالة وتشجيعها الأولاد على الاجتهاد في تحصبل العلم ونيل أعلى الدرجات للفوز بالجائزة التي أعلنت عنها، يقول: "الخالة: (تلتفت إلى الأطفال) أيها الأطفال، الخبر السار أني سأكافئ هذه المرة من يحصل منكم على أعلى الارجات في الامتحان السنوي بجائزة تسره........ اذهبوا الآن واستعدوا لإحراز المركز الأول"(94).

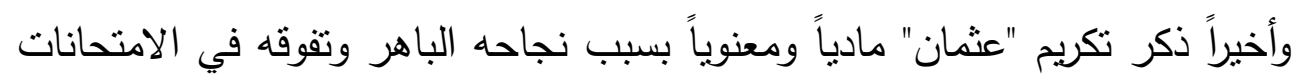
رغم مرضه لارجة أنه أحرز المركز الأول على مستوى المدرسة، الأمر الذي استحق عليه الإشادة والتكريم من الحضور في حفل تفوقه، وكذا الفوز بجائزة مادية كبيرة من خالته وسط الته تصفيق الجميع ومباركتهم له.

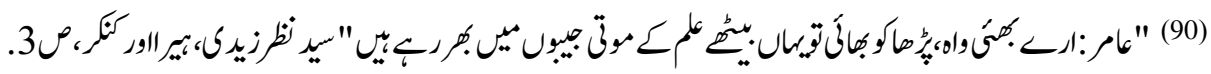

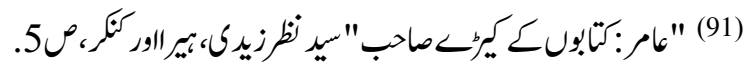

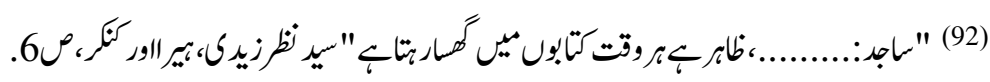

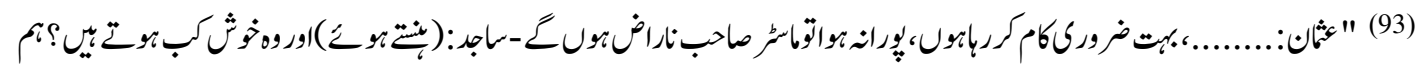

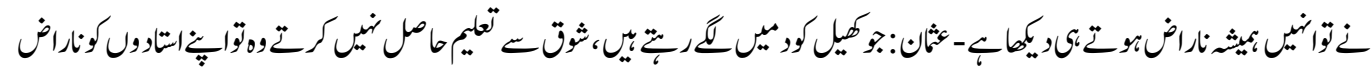

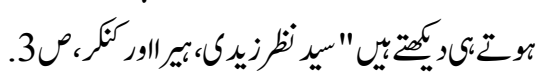

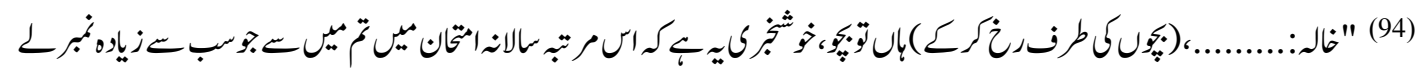

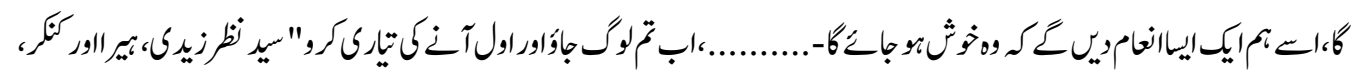

$.60^{\circ}$ 


\section{الخاتمة}

خلصت هذه الدراسة التحليلية للمجموعة المسرحية "ايمراوركنكر:الماس والحصى" إلى

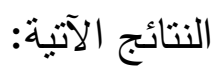

اتضح بجلاء أن المجموعة المسرحية عبارة عن مسرحيات اجتماعية أخلاقية تتطلق جميع أحداثها من البيئة المحيطة بالطفل الباكستاني، وموجهة لأطفال مرحلة الطفولة المتأخرة الممتدة من سن ثمان سنوات إلى اثتتي عشرة سنة، الأمر الذي يعكس اهتمام الأديب "سيد نظر زيدي" البالغ فيها بالقيم الاجتماعية في المقام الأول، تليها الأخلاقية، ثم الدينية، وأخيراً المعرفية، وذلك طبقاً للتحليل الوارد في الجدول الآتي: مدى تكرار القيم التريوية في المسرحيات موضوع الدراسة

\begin{tabular}{|c|c|c|c|c|c|}
\hline \multicolumn{4}{|c|}{ القيم التريوية } & \multirow[b]{2}{*}{ اسم المسرحية } & \multirow[t]{2}{*}{ p } \\
\hline القيم المعرفية & القيم الأخلاقية & القيم الدينية & القيم الاجتماعية & & \\
\hline$\sqrt{ }$ & $\sqrt{ }$ & & $\sqrt{ }$ & تيراוوركنز & 1 \\
\hline & $\sqrt{ }$ & $\sqrt{ }$ & $\sqrt{ }$ & كانكوطا & 2 \\
\hline & $\sqrt{ }$ & $\sqrt{ }$ & $\sqrt{ }$ & روطأنهلانج & 3 \\
\hline & & & $\sqrt{ }$ & روست نمارثمن & 4 \\
\hline 1 & 3 & 2 & 4 & التكرار & \\
\hline$\% 25$ & $\% 75$ & $\% 50$ & $\% 100$ & النسبة المئوية & \\
\hline
\end{tabular}

بتضح من الجدول السابق أن المجموعة المسرحية موضوع الدراسة وهي عبارة عن أربع (4) مسرحيات تحتوي -بناء على مقياس القيم السابق ذكره- على أربعة أنواع من القيم

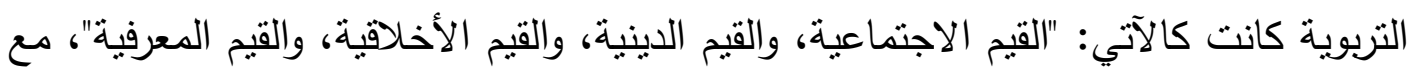
اختلاف النسب المتكررة حيث حصلت القيم الاجتماعية على أعلى النسب المتكررة في المسرحيات موضوع الدراسة بنسبة 100\%، ثم تليها القيم الاخلاقية بنسبة 75\%، ثم القيم

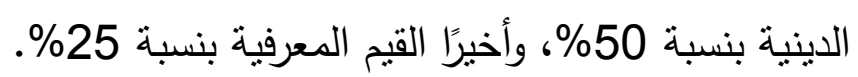
وظف الأديب البيئة المحيطة بالطفل الباكستاني من خلال استخدامه لبعض الأمثلة الحية الملموسة من الواقع المعيش للمتمع الباكستاني بغية تقريب الصورة الذهنية 
للأطفال؛ حيث ربط بين بعض القيم المقدة في المجموعة مثل قيم (التكاتف والاتحاد ومحاربة الجهل والشعوذة وترقية السلوك) وبين الواقع كي يؤدي أدب الأطفال دوره المتميز في تتمية المجتمع من خلال تعزيز القيم الإيجابية لدى أطفاله. عزز الأديب الجانب الفكري لدى الأطفال عن طريق تقديمه للشخصيات، وسلوك كل شخصية، وتسلسل الأحداث بصورة منطقية لا تعتمد على المصادفة في الوصول إلى النتائج، كما حرص على تقديم العبرة والعظة في كل مسرحية على لسان بعض شخوصها. خلت أحداث المسرحيات من الأحداث المخيفة والمزعجة للطفل، إذ جاءت المسرحيات كلها اجتماعية تدور في أحداث بسيطة، تتفاعل وتتطور بشكل نام مما يجعل المسرحيات خفيفة شيقة لدى الطفل. عمد الأديب من خلال أحداث المسرحيات إلى تحريك مشاعر الطفل وإعمال ذهنه وعقله، فيقوده ذلك إلى التفكير، وتتمية السلوك، واحترام القيم النبيلة والتحلي بها، وازدراء المفاهيم البالية والتخلي عنها. وظف الأديب مسرح الأطفال كضرورة اجتماعية تربوية من أجل غرس بعض القيم التربوية في نفوس الأطفال وتتشئتهم عليها، وتخليصهم من القيم السلبية التي تتعكس آثارها في شخصيتهم المستقبلية. لم يغفل الأديب جانب الترفيه والتسلية والمتعة جنباً إلى جنب مع بث القيم، بل حرص على تضمين مسرحياته بعض الأساليب الفكاهية للطفل في ثثايا الحوار، علاوة على حرصه على إثراء لغة الطفل، وتتمية قدراته التعبيرية عن الأفكار والمشاعر والاحتياجات. 


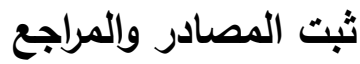

أولاً: المصادر والمراجع العربية

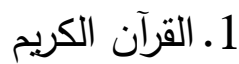

2. أحمد علي كنعان (دكتور)، أدب الأطفال والقيم التربوية، دار الفكر الدعاصر ، الطبعة

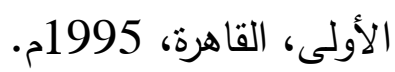

3.سمر روحي الفيصل (دكتور)، أدب الأطفال وثقافتهم، اتحاد الكتاب العرب، دمشق، 1998

4. سنن أبي داود، دار الكتب العلمية، المجلد الأول، الطبعة الأولى، بيروت، 1389هـ.

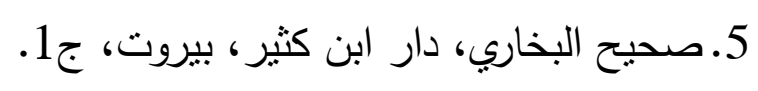

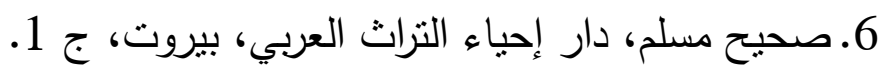

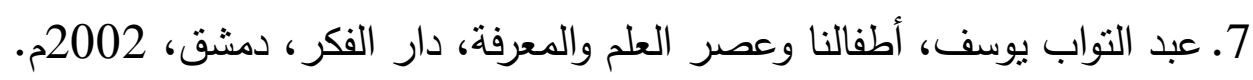

ثانياً: المصادر والمراجع الأردية

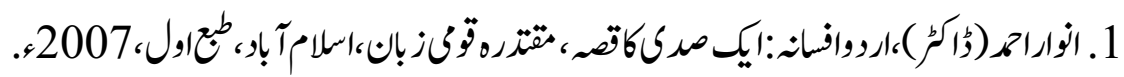

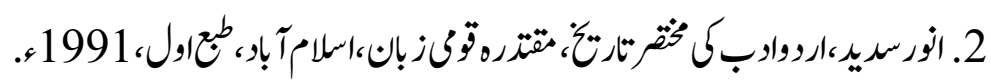

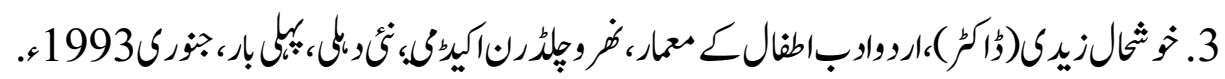

4. 3.

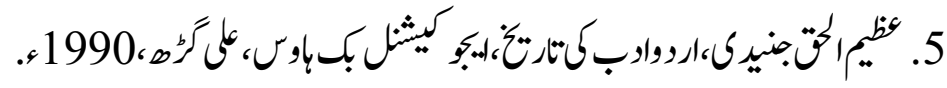

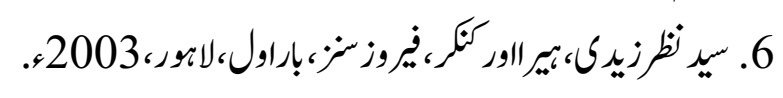

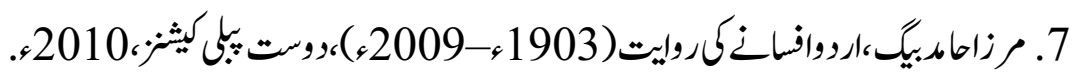

ثالثاً: المجلات والرسائل العلمية

1. محمد صوالحة، دراسة تحليلية لواقع القيم في عينة من قصص الأطفال، مجلة اتحاد

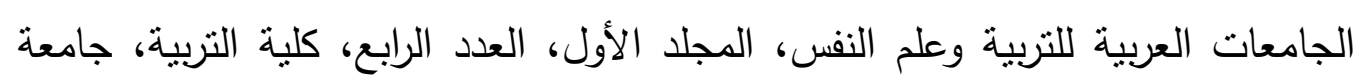

$$
\text { دمشق، 2003م. }
$$

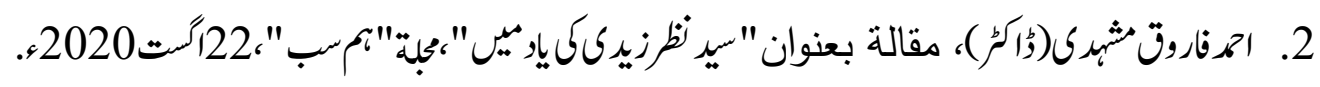





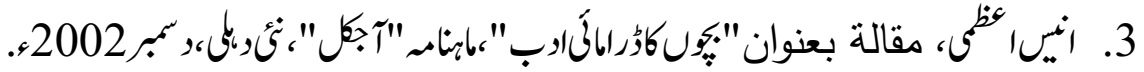

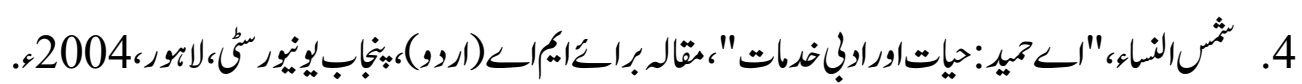

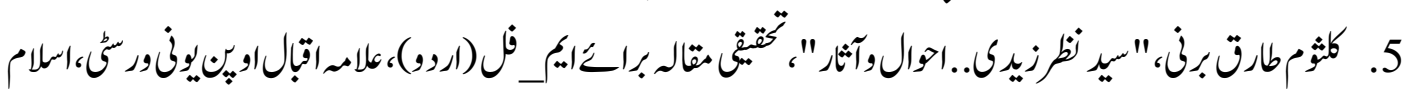
آبار،2004

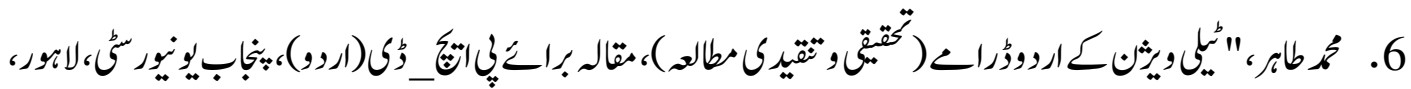
2009 
